\title{
Detection of Structural and Conformational Changes in ALS-Causing Mutant Profilin1 With Hydrogen/Deuterium Exchange Mass Spectrometry and Bioinformatics Techniques
}

\section{Ahmad Shahir Sadr}

Shahid Beheshti University https://orcid.org/0000-0001-7932-5251

zahra abdollahpour

Shahid Beheshti University

Atousa Aliahmadi

Shahid Beheshti University

Changiz Eslahchi

Shahid Beheshti University

Mina Nekouei

Shahid Beheshti University

Lily Kiaei

RockGen Therapeutics

Mahmoud Kiaei ( $\nabla$ mkiaei@uams.edu )

University of Arkansas for Medical Sciences https://orcid.org/0000-0002-0802-1426

Alireza Ghassempour

Shahid Beheshti University

\section{Research Article}

Keywords: ALS, PFN1, HDX, MALDI-TOF MS, MD Simulations, Docking Simulations

Posted Date: February 22nd, 2021

DOI: https://doi.org/10.21203/rs.3.rs-217926/v1

License: (c) (i) This work is licensed under a Creative Commons Attribution 4.0 International License. Read Full License

Version of Record: A version of this preprint was published at Metabolic Brain Disease on July 24th, 2021. See the published version at https://doi.org/10.1007/s11011-021-00763-y. 

Detection of Structural and Conformational Changes in ALS-causing Mutant Profilin1 with Hydrogen/Deuterium Exchange Mass Spectrometry and Bioinformatics Techniques

Ahmad Shahir Sadr ${ }^{1,2, \S}$ Zahra Abdollahpour ${ }^{1 \S}$, Atousa Aliahmadi ${ }^{1}$, Changiz Eslahchi ${ }^{2,3}$, Mina Nekouei $^{1}$, Lily Kiaei ${ }^{7}$, Mahmoud Kiaei ${ }^{4,5,6,7^{*}}$, and Alireza Ghassempour ${ }^{1, *}$

${ }^{1}$ Medicinal Plants and Drugs Research Institute, Shahid Beheshti University, G.C., Evin, Tehran, Iran

${ }^{2}$ Computer Science Department, Mathematical sciences faculty, Shahid Beheshti University, Tehran, Iran and ${ }^{3}$ School of Biological Sciences, Institute for Research in Fundamental Sciences (IPM), Tehran, Iran

${ }^{4}$ Department of Pharmacology and Toxicology, ${ }^{5}$ Department of Neurology, ${ }^{6}$ Department of Geriatrics, College of Medicine, University of Arkansas for Medical Sciences, ${ }^{7}$ RockGen Therapeutics, LLC, Little Rock, AR 72205, USA.

$\S$ The first two authors contributed equally to this work.

Corresponding authors:

Alireza Ghassempour, Medicinal Plants and Drugs Research Institute, Shahid Beheshti University, Tehran, Iran.

Tel: +982122431598, Fax: +982122431598

E-mail: a-ghassempour@sbu.ac.ir and a_ghassempour@yahoo.com

Mahmoud Kiaei, RockGen Therapeutics, LLC.,s

Tel:+1917-378-1373

kiaeim@rockgenbio.com or mkiaei@uams.edu

Alireza Ghassempour ORCID: 0000-0002-6435-9915

Mahmoud Kiaei : ORCID : 0000-0002-0802-1426

Changiz Eslahchi ORCID : 0000-0002-8913-3904)

Atousa Aliahmadi ORCID: 0000-0001-7932-5251

Ahmad Shahir Sadr ORCID: 0000-0001-7932-5251 


\begin{abstract}
The hydrogen/deuterium exchange (HDX) is a reliable method to survey the dynamic behavior of proteins and epitope mapping. Matrix-Assisted Laser Desorption Ionization-Time of Flight Mass Spectrometry (MALDI-TOF MS) is a quantifying tool to assay for HDX in the protein of interest. We combined HDX-MALDI-TOF MS and molecular docking/MD simulation to identify accessible amino acids and analyze their contribution in the structural changes of profilin1 (PFN1). The molecular docking/MD simulations are computational tools for enabling the analysis of the type of amino acids that may be involved via HDX identified under the lowest binding energy condition. Glycine to Valine amino acid (G117V) substitution mutation is linked to amyotrophic lateral sclerosis (ALS). This mutation is found to be in the actin-binding site of PFN1 and prevents the dimerization/polymerization of actin and invokes a pathologic toxicity that leads to ALS. In this study, we sought to understand the PFN1 protein dynamic behavior using purified wild type and mutant PFN1 proteins. The data obtained from HDX-MALDI-TOF MS for PFN1 ${ }^{\mathrm{WT}}$ and PFN1 ${ }^{\mathrm{G} 117 \mathrm{~V}}$ at various time intervals, from seconds to hours, revealed multiple peaks corresponding to molecular weights from monomers to multimers. PFN1/Benzaldehyde complexes identified 20 accessible amino acids to HDX that participate in the docking simulation in the surface of WT and mutant PFN1. Consistent results from HDX-MALDI-TOF MS and docking simulation predict candidate amino acid(s) involved in the dimerization/polymerization of $\mathrm{PFN}^{\mathrm{G} 117 \mathrm{~V}}$. This information may shed critical light on the structural and conformational changes with details of amino acid epitopes for mutant PFN1s' dimerization, oligomerization, and aggregation.
\end{abstract}

Keywords: ALS, PFN1, HDX, MALDI-TOF MS, MD Simulations, Docking Simulations

\title{
Abbreviations
}

ALS: amyotrophic lateral sclerosis, PFN1: Profilin 1, HDX: hydrogen/deuterium exchange, MALDI-TOF MS: Matrix-Assisted Laser Desorption Ionization-Time of Flight Mass Spectrometry, MD: Molecular Dynamics, PDB: Protein Data Bank

Data Availability Statement: All data generated or analyzed during this study are included in this published article and its supplementary information files as a movie can be found in the link shown here:

https://doi.org/10.6084/m9.figshare.13551218

\section{Author's Contribution:}

The concept and idea of the study was conceived and designed by MK, CE, ZA, MN, ASS, AG. The experiments were designed and carried out by ZA, AA, MN, ASS. The data were analyzed and evaluated by MK, CE, ASS, AG. The manuscript was written by MK, CE, ASS, ZA, LK, AG. 


\section{Introduction}

Amyotrophic lateral sclerosis (ALS) is a progressive neurodegenerative disorder, in which the motor neurons in the brain and spinal cord controlling the voluntary movement of skeletal muscles degenerate. As a result, voluntary skeletal muscles lose connection with motor neurons, resulting in muscle paralysis and eventual death of ALS patients (Zarei et al. 2015).

Profilin1 (PFN1) is a ubiquitous protein and abundantly expressed in the body (Witke 2004, Lee and Kim 2015, Alkam et al. 2017). PFN1 is a small protein with 140 amino acid residues for its well-known function in converting G-actin to F-actin in actin polymerization. De novo PFN1 function is necessary for all basic cellular activities during development as it is involved in the formation of neuronal cytoskeleton, development of axons and dendrites, synaptogenesis (Kiaei et al. 2018).

Eight known mutations in PFN1 (A19T, C70G, T108M, M113T, E116G, G117V, R136W, and Q139L) are associated with human ALS (Wu et al. 2012, Chen et al. 2013, Kiaei et al. 2018). The wild type PFN1 (PFN1 ${ }^{\mathrm{WT}}$ ) tertiary structure is formed by seven antiparallel $\beta$-sheets and five $\alpha$ helices that two of these are located at the termini (Schutt et al. 1993, Metzler et al. 1995, Krishnan et al. 2009, Alkam et al. 2017). The glycine to valine $\left(\mathrm{PFN} 1^{\mathrm{G} 117 \mathrm{~V}}\right)$ substitution and threonine to methionine ( $\mathrm{PFN} 1^{\mathrm{T} 108 \mathrm{M}}$ ) substitution are two mutations that cause the most changes in the protein stability and actin binding ability of PFN1. Therefore, we sought to understand the changes and the impact of these mutations. We and others previously reported that hydrophobicity of the interactive regions increases and the flexibility between $\alpha$-helix and $\beta$-sheet decreases due to glycine to valine substitution, which leads to the reduction or the loss of actin binding (Alkam et al. 2017, Zhang et al. 2019).

Mass spectrometry (MS) technique has become a powerful tool for the characterization of higher-order structure of protein (Englander 2006, Montalvao et al. 2008, Rozbesky et al. 2012, Hentze and Mayer 2013, Leurs et al. 2015, Xiao et al. 2015, Kochert et al. 2018, Xiao et al. 2018), protein dynamics, conformations (Lodowski et al. 2010, Majumdar et al. 2015), protein motion/flexibility (Zhou and Robinson 2014) and ligand-protein binding (West et al. 2011). Hydrogen-deuterium exchange linked with mass spectrometry (HDX-MS) technique is a valuable and powerful method for studying higher-order structure of protein (Englander 2006, Hentze and Mayer 2013, Leurs et al. 2015, Majumdar et al. 2015) that provides a read-out in the changes in solvent accessibility and hydrogen bonding exclusively and in the complexes of proteins in a solution (Zhang and Smith 1993, Figueroa and Russell 1999, Villanueva et al. 2000, Englander et al. 2003, Busenlehner and Armstrong 2005, Maier and Deinzer 2005, Englander 2006, Wales and Engen 2006, Palashoff 2008, Wei et al. 2014, Weis 2016). The goal of this study was to gather data on these and analyze the amino acids that may be affected by the mutation and determine the steps in the aggregation of mutant PFN1. This kind of pathology is proven to cause ALS in human and mouse models (Wu et al. 2012, Fil et al. 2017).

The dimerization/polymerization of PFN1 ${ }^{\mathrm{WT}}$ and $\mathrm{PFN} 1^{\mathrm{G} 117 \mathrm{~V}}$ was the subject of several recent studies (Lambrechts et al. 2002, Nekouei et al. 2018). We analyzed the purified PFN1 ${ }^{\mathrm{WT}}$ and PFN1 ${ }^{\mathrm{G} 117 \mathrm{~V}}$ protein samples expressed in E. Coli and probed to determine the structural and 
conformational changes by identification of accessible amino acids from HDX-MALDI-TOF MS. We then used molecular dynamic simulation as a reliable approach that enables understanding the structure-to-function relationships of proteins (Hospital et al. 2015) to determine the number and type of amino acids involved in HDX and the changes impacted the structure of mutant PFN1.

\section{Materials and Methods}

\section{Recombinant PFN1 proteins expression and optimization of expression conditions}

Wild type PFN1and mutant PFN1 ${ }^{\mathrm{G} 117 \mathrm{~V}}$ cDNA were cloned into $p E T 21 a$ (Nekouei et al. 2018). The PFN1 constructs transfected into E. Coli BL21 host cells and grew in LB medium (Liofilchem, Italy) containing $100 \mu \mathrm{g} / \mathrm{mL}$ ampicillin and to obtain higher yields of recombinant PFN1 proteins, the expression conditions optimized. IPTG concentration $(0.2,0.4,0.6,0.8$ and $1 \mathrm{mM})$ was used to induce expression and the times for induction were $(2 \mathrm{~h}, 4 \mathrm{~h}$ and overnight $)$ in $20{ }^{\circ} \mathrm{C}$ to obtain optical density at $600 \mathrm{~nm}$ of 0.6 (Fedorov et al. 1994). Cells were pelleted down by centrifugation, resuspended, and sonicated in Tris- $\mathrm{HCl} 50 \mathrm{mM}$ and $\mathrm{NaCl} 150 \mathrm{mM}, \mathrm{pH}$ 7.4. Initially, this solution was centrifuged for $5 \mathrm{~min}(2,000 \mathrm{rpm})$, then for $15 \mathrm{~min}(13,000 \mathrm{rpm})$. This protocol is according to reference (Lambrechts et al. 2002) and modified for IPTG (Isopropyl- $\beta$-D-thiogalactoside) concentrations, induction times, and temperatures used to increase the efficiency and yield of PFN1 protein.

\section{PFN1 purification by poly-L-proline Sepharose Column}

In this study, we prepared and used the buffers as described in Nekouei et al., (Nekouei et al. 2018) with minor modifications to improve the coupling/binding process. So, 0.1 gram of $\mathrm{CNBr}$ activated sepharose and allowed it to be hydrated in $30 \mathrm{ml}$ of $1 \mathrm{mM}$ HCI until settled down. Sepharose resin was centrifuged for $3 \mathrm{~min}$ and washed with deionized water. Poly-L proline (Sigma-Aldrich, USA) was dissolved in the coupling buffer (0.5 M NaCl and 0.5 M NaCl, pH 8.5), mixed with the CNBr activated Sepharose resin, and stirred for $20 \mathrm{~h}$ at $4{ }^{\circ} \mathrm{C}$. Next, Poly-L proline was added and allowed to bind to the resin and the mixture was washed with $0.5 \mathrm{M} \mathrm{NaCl}$ and 0.1 $\mathrm{M}$ Tris- $\mathrm{HCl}(\mathrm{pH} 8.0$ ) for $2 \mathrm{~h}$ to remove any unbound poly-L proline. The resin was washed with 3 $\mathrm{ml}$ of $0.1 \mathrm{M} \mathrm{HCl}(\mathrm{pH} \mathrm{8.0)}$ ) and stirred for $2 \mathrm{~h}$. The poly (L-proline)-sepharose column was equilibrated with a wash buffer containing (20 mM Tris, $0.2 \mathrm{mM} \mathrm{NaN3}, 0.1 \mathrm{mM} \mathrm{CaCl}$, and 2 mM DTT, $\mathrm{pH}$ 7.3). This supernatant was diluted with the wash buffer and placed in an ice bath with moderate stirring for $2 \mathrm{~h}$. The PFN1 was eluted from the poly (L-proline)-sepharose column with the wash buffer without adding Urea. Ultimately, Vivaspin ${ }^{\circledR}$ centrifugal concentrators $(5 \mathrm{kDa}$ molecular-weight cutoff) tubes were used to purify and concentrate PFN1 protein samples. 


\section{Polyacrylamide gel electrophoresis (PAGE) analysis}

Tris glycine SDS-PAGE (15\%) with Laemmli buffer (Lambrechts et al. 2002) was used to separate the protein samples. The sample buffer (3 M glycerol, 10\% SDS, $0.5 \mathrm{M}$ Tris-HCl pH 6.8, $0.05 \%$ bromophenol blue) was added to the protein samples. Protein samples were loaded on SDSPAGE precast gel and the interior chamber of the gel tank filled with running buffer and electrical power applied to start electroproses. The gel was removed from the cast and stained with silver nitrate or Coomassie Brilliant Blue G-250 staining to visualize the bands.

\section{Identification of protein using MALDI-TOF MS}

Intact PFN1 protein samples were analyzed by MALDI-TOF MS (Applied Bio systems model 4800 MALDI-TOF MS, Waltham, Massachusetts, USA) according to the protocol described in (Lambrechts et al. 2002) using $\alpha$-cyano-4-hydroxycinnamic acid matrix solution containing 50\% acetonitrile containing $0.1 \%$ trifluoroacetic acid. To calibrate the system, equine cytochrome $\mathrm{c}$ (average mass 12,362 Da) as internal standards and Equine Apo-myoglobin (average mass 16,952 $\mathrm{Da}$ ) as external standards were used. The protein samples were mixed with matrix at a ratio of 1:2 and then $1 \mu \mathrm{L}$ of mixture was spotted onto the chilled MALDI plate and placed under a chiller until spots dried. The matrix and samples were incubated on ice and vortexed before use. MALDITOF MS analysis was done in linear positive mode. Also, PFN1 proteins were identified by in-gel trypsin digestion. Spots/bands of protein of interest were selected and excised. To wash out the stain from the excised bands, they were washed with a bicarbonate buffer and acetonitrile. IAA alkylating agent was used to reduce disulfide bonds (Shevchenko et al. 2006). Trypsin used to digest the protein samples at the peptide bonds from carboxyl terminal where arginine and lysine can be found. The peptides samples and $\alpha$-cyano-4-hydroxycinnamic acid matrix were mixed at a ratio of 1:2 and then $1 \mu \mathrm{L}$ aliquot was spotted onto the MALDI plate and analyzed in reflector positive mode. The Swiss-Protein database was used to search the data generated in this study.

\section{Preparation of protein sample for HDX by MALDI-TOF MS}

Experiments were carried out to evaluate rates of deuterium $\left(\mathrm{D}_{2} \mathrm{O}\right)$ into the amide positions in PFN $1^{\mathrm{WT}}$ and PFN1 ${ }^{\mathrm{G} 117 \mathrm{~V}}$ proteins. For non-deuterated procedure, samples of PFN1 (1000 ppm) were diluted in $150 \mathrm{mM} \mathrm{NaCl}$ plus $8.3 \mathrm{mM}$ Tris $\mathrm{pH} 7.3$ at a ratio of $1: 3$ in $\mathrm{H} 2 \mathrm{O}$ solution at $0^{\circ} \mathrm{C}$ for $1 \mathrm{~min}$. Then, $36 \mu 1$ of the quenched solution was added to $24 \mu 1$ of protein sample and incubated for $1 \mathrm{~min}$ on ice. Protein samples were incubated in a D2O buffer $(150 \mathrm{mM} \mathrm{NaCl}$ pulse $8.3 \mathrm{mM}$ Tris, $\mathrm{pH} 7.3$, in $\mathrm{D}_{2} \mathrm{O}$ ) at a ratio of 3:1 in for $10 \mathrm{~s}$ and 2, 4, 10 and $420 \mathrm{~min}$.

Analysis for HDX used the MALDI-TOF MS operated in MS Linear positive mode with the optimized source settings factors for HDX and intact samples: mass range 10,000-20,000 Da and detector voltage 0.84 with the laser intensity 5700 . Also, the exact mass of PFN $1{ }^{\text {WT }}$ and PFN $1{ }^{\text {G117V }}$ was calculated in the https://web.expasy.org/compute_pi/ tool to calculate the mass changes for before and after deuteration. 


\section{Molecular dynamic simulation technique}

The PFN1 ${ }^{\mathrm{G} 117 \mathrm{~V}}$ mutation, which is the same as G118V for rodents, structure has not yet been resolved in the protein data bank (rcsb.org), and in this study a point mutation (G117V) was inserted using the Swapaa command by the Chimera program software (Ferrin et al. 1988, Pettersen et al. 2004). Molecular dynamics simulation for $100 \mathrm{~ns}$ was carried out to obtain protein structure profile. The appropriate PDBID: 1FIK structure was obtained from the Protein Data Bank (rcsb.org) and prepared by UCSF Chimera program. The Swapaa command of chimera program was used to create G117V point mutation on PFN1, and the final structure of the mutated PFN1 $\left(\mathrm{PFN} 1^{\mathrm{G} 117 \mathrm{~V}}\right.$ ) was obtained by performing $100 \mathrm{~ns}$ of molecular dynamics simulation by the Gromacs 2018 program (Lemkul 2018). The structure of the PFN1 ${ }^{\text {WT }}$ was also simulated for 100 ns by Gromacs (Figs. 1, 2). Fragments such as acetaldehyde and benzaldehyde were used to find the hotspots of a protein used. Once the structure of two small fragments were downloaded from the PubChem data bank (e.g. Kim et al. 2019), we began to optimize their energy structure by Gaussian03 optimized fragment structures (Gaussian03 2004) were randomly probed 220 times around PFN1 $1^{\mathrm{WT}}$ and $\mathrm{PFN} 1^{\mathrm{G} 117 \mathrm{~V}}$ by the Autodock 4 program. The regions of tendency to be coupled with the corresponding binding energy were finally clustered and identified (Table 1S$4 \mathrm{~S})$. Small fragments such as acetaldehyde and benzaldehyde are used to find the hotspots of a protein in a method known as FTMAP (Ngan et al. 2012). Spots that group molecular fragments predict the drug's sites of interest for binding. In this study, we used two small molecular structures called acetaldehyde and benzaldehyde.

\section{Obtaining, modeling and optimization of structures}

\section{Small fragments}

The primary structures of acetaldehyde and benzaldehyde were obtained from PubChem structural database with unique chemical identification (CID) 177 and 240, respectively. These were optimized for geometrical energy and spatial structure. The Gauss View program provided the necessary outputs for the Gaussian03 program while making initial changes (Frisch et al. 2004). In this program, using the DFT/B3LYP protocol, we obtained the optimal structure by the command line, thus providing the acetaldehyde and benzaldehyde small ligand model for further use (Table 1).

\section{Molecular docking simulation}

Molecular docking simulation by Autodock 4.2 software was used to identify the hotspots of PFN1 protein. In the first phase, acetaldehyde and benzaldehyde were randomly displaced at the PFN1 surface, took 220 runs to find their ideal PFN1 binding site as hotspots (Morris et al. 2009). 


\section{Insertion of point mutation on PFN1 and docking simulation to identify hotspots}

To find the amino acids involved in the hotspot of mutant protein $(\mathrm{G} 117 \mathrm{~V})$, the protein structure with the mutation needed to be generated first, since the structure of the mutant protein was not found in the protein database. To obtain this structure, we used the method of inserting a point mutation by the Swapaa command line by UCSF-Chimera. The position of residue 117 was changed from Glycine to Valine. A change in any amino acid can affect the overall structure of any protein which appears to be the case for PFN1. To observe the changes in the tertiary structure of the mutant PFN1, the structure was simulated by a molecular dynamics program for $100 \mathrm{~ns}$. This condition of molecular dynamics simulation will show the amino acid residues in a most optimal dynamic state. The simulation of the molecular dynamics residue 117 reveals its effects on the structure. To further investigate the effects of G117V mutation on PFN1, we carried out molecular dynamic simulations using the Gromacs 2018 package. The $\mathrm{x}$-ray crystal structures data of PFN1 (PDB ID:1FIK) is from wild type protein and G117V mutation introduced and molecular dynamic simulations ran for $100 \mathrm{~ns}$ in three replicates. The generated trajectories were evaluated according to their RMSD, RMSF, RG, intramolecular Hb characteristics.

\section{Results and Discussion}

\section{Protein expression optimization, affinity purification and mass spectrometry}

Bacterial culture from transfected cells were used to express wild type and mutant PFN1 proteins (Fig. 1S). The protein synthesis induction time was from $4 \mathrm{~h}$ to $20 \mathrm{~h}$ (Table 4S), and overnight at $20^{\circ} \mathrm{C}$ (Fig. 2S), and the recovery and purification of PFN1 protein improved significantly (10-20\%). To extract PFN1 protein from E. Coli bacterial culture, bacterial cells were separated from the media at low speed (2000 rpm), to prevent lysis initially and then pelletized at 13,000 rpm. The suspended pellet was separated into water-soluble and insoluble proteins fractions. A small volume from each fraction was prepared to load on SDS-PAGE to analyze the expressed proteins and confirmed the protein in the band around size (14-15 kDa) as PFN1, as it is close to the size of the recombinant PFN1 (Fig. 3S).

This was further confirmed by MALDI-TOF MS peaks (Fig. 3). The purification of PFN1 ${ }^{\text {WT }}$ and $\mathrm{PFN} 1^{\mathrm{G} 117 \mathrm{~V}}$ were performed without urea, to maintain protein folding and conformation, and eliminate the need of dialysis. The bands were excised, digested, and analyzed with MALDI-TOF MS. The peptides sequences were obtained and searched in Swiss-Prot database. Among the mixture of peptide sequences, 14 peptides obtained for the complete digestion of PFN $1^{\mathrm{WT}}$ ( $71 \%$ sequence coverage) and 9 peptides from the incomplete digestion of $\mathrm{PFN} 1^{\mathrm{G} 117 \mathrm{~V}}$ (47\% sequence coverage). 


\section{HDX analysis using MALDI-TOF MS}

The idea of using HDX was to examine the active sites of PFN1 ${ }^{\mathrm{WT}}$ in comparison to PFN1 ${ }^{\mathrm{G} 117 \mathrm{~V}}$. This assay allows the monitoring of the speed of dimerization/polymerization using HDX and MALDI-TOF MS as useful parameters in understanding the mechanisms in controlling/developing ALS. This approach allowed us to predict possible hotspots regions in the PFN1 protein to introduce suitable candidates to indicate binding with these points. We calculated molecular weights of $16,763 \mathrm{Da}$ for PFN1 ${ }^{\mathrm{WT}}$ and $16,662 \mathrm{Da}$ for FPN1 ${ }^{\mathrm{G} 117 \mathrm{~V}}$ by using the spectra related to PFN1 ${ }^{\mathrm{WT}}$ and PFN1 ${ }^{\mathrm{G} 117 \mathrm{~V}}$ samples. The ratio of the masses for PFN1 ${ }^{\mathrm{WT}}$ in $10 \mathrm{~s}, 2 \mathrm{~min}, 4 \mathrm{~min}, 10$ min and $7 \mathrm{~h}$ were 23, 40, 86, 97 and $238 \mathrm{Da}$ and for PFN1 ${ }^{\mathrm{G} 117 \mathrm{~V}}$, were 14, 40, 65, 133 and $242 \mathrm{Da}$, respectively. These differences indicate that the active hydrogens in the first minutes and the other hydrogens with less activity in the following minutes would participate in the exchange reaction (Table 2).

These results are consistent to our previous findings reported in Nekouei et al.,(Nekouei et al. 2018) that the dimerization/polymerization of $\mathrm{PFN}^{\mathrm{G} 117 \mathrm{~V}}$ related to $\mathrm{PFN} 1^{\mathrm{WT}}$ was rather rapid MALDI-TOF MS showed dimer and polymer form of $\mathrm{PFN}^{\mathrm{G} 117 \mathrm{~V}}$ in the samples of mutant PFN1 as observed by the appearance of cloudiness in the solution indicating spontaneous oligomerization. The lower values in $\mathrm{HDX}$ for $\mathrm{PFN}^{\mathrm{G} 117 \mathrm{~V}}$ compared with $\mathrm{PFN} 1^{\mathrm{WT}}$ samples can be related to speed of dimerization and reduced available hydrogen for exchange than in the PFN1 ${ }^{\mathrm{WT}}$ that is in monomer form.

Next, we performed molecular docking simulation and identified the amino acids involved in the binding of PFN1 ${ }^{\mathrm{WT}}$ and $\mathrm{PFN}{ }^{\mathrm{G} 117 \mathrm{~V}}$ to the small ligands like acetaldehyde and benzaldehyde (Table 3).

Based on predictions by molecular docking simulation and according the lowest binding energy, in the binding of PFN1 ${ }^{\mathrm{WT}}$ and $\mathrm{PFN}^{\mathrm{G} 117 \mathrm{~V}}$ to acetaldehyde ligand, the amino acids Gln 79 , Thr 64, Lys 25, Asn 99, Leu 78 and Arg 55, Tyr 24, Lys 25 were found to be involved in this binding positioned on the surface of PFN1 ${ }^{\mathrm{WT}}$ and $\mathrm{PFN}^{\mathrm{G} 117 \mathrm{~V}}$, respectively. We found 16 and 22 exchangeable hydrogen, comparing them to experimental change of mass to charge related to $\mathrm{PFN}^{\mathrm{WT}}$ and PFN ${ }^{\mathrm{G} 117 \mathrm{~V}}, 14$ and 23 Da changes after 10 seconds of incubation with deuterium based HDX method. Therefore, we conclude that these amino acids are hotspot residues on the surface of the PFN1 $1^{\mathrm{WT}}$ and $\mathrm{PFN}{ }^{\mathrm{G} 117 \mathrm{~V}}$ that begin to be exchanged in the first minutes. It is possible to propose that these amino acids and related hydrogens are the initial steps of the dimerization/polymerization of $\mathrm{PFN}^{\mathrm{G} 117 \mathrm{~V}}$ related to $\mathrm{PFN} 1^{\mathrm{WT}}$. The experimental and in silico data are consistent and confirm the hotspots by mass-spectroscopy, MD simulations and Molecular Docking simulations.

Also, the change of mass to charge related to PFN1 ${ }^{\mathrm{WT}}$ and $\mathrm{PFN}^{\mathrm{G} 117 \mathrm{~V}}$ was $40 \mathrm{Da}$ after 2 min incubation in both cases. This is consistent with the pre-folded structures of PFN1 ${ }^{\mathrm{WT}}$ and PFN1 ${ }^{\mathrm{G} 117 \mathrm{~V}}$ where $\beta$-sheet and $\alpha$-helices have not formed yet for their special dimension structures. Therefore, PFN1 ${ }^{\mathrm{WT}}$ and PFN1 ${ }^{\mathrm{G} 117 \mathrm{~V}}$ show similar HDX behavior. In molecular docking simulation, surface amino acids which participate in binding with $\mathrm{PFN} 1^{\mathrm{WT}}$ to benzaldehyde and acetaldehyde and PFN1 ${ }^{\mathrm{G} 117 \mathrm{~V}}$ to benzaldehyde complexes are Trp 31, Arg 74, Arg 135, Asn 99, Gln 79, Thr 64, 
Lys 25, Leu 78 and Val 118, Lys104, Asp 54, Asn 124, Ile 123, Tyr59, Asp106, Lys 25, Tyr 54 with 40 and 37 accessible hydrogens, respectively (Table 3).

In the longer incubation, the PFN1 proteins incubated during $4 \mathrm{~min}$ with deuterium. The changes of mass to charge for PFN $1{ }^{\mathrm{WT}}$ and $\mathrm{PFN}^{\mathrm{G} 117 \mathrm{~V}}$ in mass spectrometry results were 86 and 65 $\mathrm{Da}$, Respectively. Based on native mass spectrometry data of PFN1, we discover the second type of hydrogens after 4 min of incubation which do not appear in the first wave to HDX, which could be because they were hidden in the folded structures of PFN1.

In molecular docking simulation, time isn't taken as a parameter during interactions analysis and benzaldehyde and acetaldehyde interactions followed as the next step, with PFN1 and looked for any correlation between the docking data and experimental HDX data. The amino acids located on the surface of PFN1 that may participate in binding to benzaldehyde and acetaldehyde complexes were found to be Arg 55, Tyr 24, Lys 25, Phe 83, Val 118, Lys104, Asp 54, Asn124, Ile 123, Tyr59, Asp106, Lys 25, Tyr 54. The surface amino acids which participate in binding with PFN $1{ }^{\text {WT }}$ to benzaldehyde and acetaldehyde complexes found to be Trp 31, Arg 74, Arg 135, Asn 995, Gln 79, Thr 64, Lys 25, Leu 78 with the intra-amino acids with lower activity than surface amino acids with 54 and 86 accessible hydrogens, respectively (Table 1S-4S). The molecular docking simulation of $\mathrm{PFN} 1^{\mathrm{G} 117 \mathrm{~V}}$ using computer programs is presented in the form of figures (Figs. 5, 6) and tabulated data presented in table 3 and further demonstrated with a short animation (Supp. Movie).

According to the results and comparison of the experimental and molecular docking simulation data, the amino acids identified as hotspots on the surface of the PFN $1^{\mathrm{WT}}$ and $\mathrm{PFN} 1^{\mathrm{G} 117 \mathrm{~V}}$ have been located. 


\section{Conclusion}

In this study we optimized the method to express recombinant wild type and mutant PFN1 proteins for HDX MALTI-TOF MS analysis. The optimization enabled higher yield and recovery by varying the time and IPTG concentration. HDX MALDI-TOF MS results were compared to molecular dynamic study of HDX of the PFN1 ${ }^{\mathrm{WT}}$ and PFN1 ${ }^{\mathrm{G} 117 \mathrm{~V}}$.

After the incubation of PFN1 ${ }^{\mathrm{WT}}$ and $\mathrm{PFN} 1^{\mathrm{G} 117 \mathrm{~V}}$ within 10 seconds, 2, 4 minutes with deuterium, changes of mass to charge were investigated, and we found that in 10 seconds, PFN1 ${ }^{\mathrm{WT}}$ and PFN1 ${ }^{\mathrm{G} 117 \mathrm{~V}}$ showed a change of 23 and $14 \mathrm{Da}$, respectively. This indicates that only the active amino acids on the protein surface were exchanged during this short period of time. During the 2 minutes incubation, the mass-to-charge ratio of PFN1 ${ }^{\mathrm{WT}}$ and PFN1 ${ }^{\mathrm{G} 117 \mathrm{~V}}$ changed to 40 Da for both proteins, and in 4 minutes, that increased to 86 and $65 \mathrm{Da}$, respectively. This indicates that other active amino acids on the surface have exchanged. Also, in the study of molecular docking simulation and comparison of results based on the lowest binding energy, surface amino acids Gln 79, Thr 64, Lys 25, Asn 99, Leu 78 and Arg 55, Tyr 24, Lys 25 that have participated in the binding of PFN1 ${ }^{\text {WT }}$ with acetaldehyde and PFN1 ${ }^{\mathrm{G} 117 \mathrm{~V}}$ with acetaldehyde have 22 and 16 hydrogen exchangeable, respectively. We have noticed consistency between the theoretical data obtained

using in silico programs and experimental data using wet laboratory devices, and they happen to be in agreement with each other in identifying the amino acids that are most likely involved and may be affected with Gly117Val mutation. 


\section{Legends:}

\section{Table Legends:}

Table 1. Molecular formula, CID, CAS\#, and 2D, 3D structure of benzaldehyde / acetaldehyde.

Table 2. Experimental data of accessible amino acid hydrogens in protein samples.

Table 3. Molecular docking simulation of PFN1 demonstrate interaction with small ligands 


\section{Supplementary Table Legends:}

Table 1S. Distinct conformational clusters found, out of 220 runs of acetaldehyde over PFN1 ${ }^{\mathrm{G} 117 \mathrm{~V}}$, using RMSD -tolerance of $2.0 \mathrm{~A}$

Table 2S. Distinct conformational clusters found, out of 220 runs of acetaldehyde over PFN1 ${ }^{\text {WT }}$, using RMSD -tolerance of $2.0 \mathrm{~A}$

Table 3S. Distinct conformational clusters found, out of 220 runs of benzaldehyde over PFN1 ${ }^{\mathrm{G} 117 \mathrm{~V}}$, using RMSD -tolerance of $2.0 \mathrm{~A}$

Table 4S. Distinct conformational clusters founding, out of 220 runs of benzaldehyde over $\mathrm{PFN}^{\mathrm{WT}}{ }^{\mathrm{W}}$, using RMSD-tolerance of $2.0 \mathrm{~A}$ 


\section{Figure Legends:}

Figure 1. Backbone RMSD and Radius of Gyration $(\mathrm{Rg})$ of $P F N 1^{\mathrm{G} 117 \mathrm{~V}}$ a. The RMSD for the backbone atoms of the mutant-type structure at 300k shown as a function of time. $\mathbf{b}$. the $\mathrm{Rg}$ for the $\mathrm{Ca}$ atoms of the mutant-type PFN1 at 300k is shown as a function of time.

Figure 2. RMSF of the Mutant-type PFN1 and intramolecular hydrogen bond ( $\mathrm{Hb})$. a. The RMSF of the PFN1 Mutant type at 300k is shown. b. The number of intra-molecular Hb formed at 300k throughout the simulations is shown as a functions of time.

Figure 3. a. Silver nitrate staining in SDS-PAGE related to $P F N^{\mathrm{WT}}$ and $\mathrm{PFN} 1^{\mathrm{G} 117 \mathrm{~V}}$ purification using poly-L-proline sepharose column. Proteins band showed that in molecular weight of 14-15 $\mathrm{kDa}$ is related to PFN1 proteins. b. MALDI-TOF MS spectra related to intact PFN1 ${ }^{\mathrm{WT}}$. c. MALDITOF MS spectra related to intact PFN1 ${ }^{\mathrm{G} 117 \mathrm{~V}}$. Black arrows point to pure PFN1 band stained with silver staining.

Figure 4. MALDI-TOF MS spectrum of time dependent deuterated and non-deuterated samples a. spectrum related to ND PFN1 ${ }^{\mathrm{WT}}$. b. The spectrum related to ND PFN1 ${ }^{\mathrm{G} 117 \mathrm{~V}}$. c. Pulse deuterated PFN1 ${ }^{\text {WT }}$ during 10s. d. Pulse deuterated PFN1 ${ }^{\mathrm{G} 117 \mathrm{~V}}$ during 10 s. e. Continues deuterated related to $P F N 1{ }^{\text {WT }}$ during 2 min. f. Continuous deuterated related to $P F N 1{ }^{\mathrm{G} 117 \mathrm{~V}}$ during 2 min. g. Continuous deuterated related to $\mathrm{PFN} 1^{\mathrm{WT}}$ during $4 \mathrm{~min}$. h Continuous deuterated related to $\mathrm{PFN} 1^{\mathrm{G} 117 \mathrm{~V}}$ during 4 min. i. Continuous deuterated related to $P F N 1{ }^{\text {WT }}$ during $10 \mathrm{~min}$. j. Continuous deuterated related to $P F N 11^{\text {G117V }}$ during 10 min. k. Continuous deuterated related to PFN1 ${ }^{\text {WT }}$ during 7 h. l. Continuous deuterated related to $\mathrm{PFN} 1^{\mathrm{G} 117 \mathrm{~V}}$ during $7 \mathrm{~h}$.

Figure 5. Molecular docking simulations of binding of $\mathrm{PFN} 1^{\mathrm{WT}}$ to Acetaldehyde and Benzaldehyde. a. The hotspots amino acids on the surface of PFN ${ }^{\mathrm{WT}}$ related to PFN1 ${ }^{\text {WT }}$ /Acetaldehyde by Lys25, Thr64, Leu78, Gln79 and Asn 99. b. The amino acids involved in the hotspots on the surface of PFN1 ${ }^{\text {WT }}$ related to PFN1 ${ }^{\text {WT }}$ / Benzaldehyde are Trp31, Arg 74 and Arg135. An animated presentation of this data is available in supplementary data section. (Supp. movie)

Figure 6. Molecular docking simulations of binding of $\mathrm{PFN} 1^{\mathrm{G} 117 \mathrm{~V}}$ to Acetaldehyde and Benzaldehyde. a. The amino acids involved in the hotspots on the surface of PFN1 ${ }^{\mathrm{G} 117 \mathrm{~V}}$ related to PFN1 ${ }^{\mathrm{G} 117 \mathrm{~V}} /$ Acetaldehyde by Tyr24, Lys25, Arg55, Tyr59, Val60 and Phe83. b. The amino acids involved in the hotspots on the surface of PFN1 ${ }^{\mathrm{G} 117 \mathrm{~V}}$ related to $\mathrm{PFN} 1^{\mathrm{G} 117 \mathrm{~V}} / \mathrm{Benzaldehyde}$ are Tyr24, Lys25, Asp54, Tyr59, lys104, Asp106, Val118, Ile123, and Asn124. An animated presentation of this data is available in supplementary data section. (Supp. movie) 


\section{Supplementary Figure Legends:}

Figure 1S. Coomassie blue SDS-PAGE related to the IPTG concentration optimization of PFN1 ${ }^{\text {WT }}$ and PFN $1^{\mathrm{G} 117 \mathrm{~V}}$. a. Optimization of IPTG concentration related to PFN1 ${ }^{\mathrm{WT}}$ in different IPTG molarity. From left to right: ladder, before induction (BI) , $0 \mathrm{mM}, 0.2 \mathrm{mM}, 0.4 \mathrm{mM}, 0.6 \mathrm{mM}, 0.8 \mathrm{~m}$ $\mathrm{M}$ and $1 \mathrm{mM}$ of IPTG during $20 \mathrm{~h}$ after induction. b. Optimization of IPTG concentration related to PFN $1^{\mathrm{G} 117 \mathrm{~V}}$ in different IPTG molarity, from left to right: before induction, ladder, $0 \mathrm{mM}, 0.2$ $\mathrm{mM}, 0.4 \mathrm{mM}, 0.6 \mathrm{mM}, 0.8 \mathrm{mM}$ and $1 \mathrm{mM}$ of IPTG during $20 \mathrm{~h}$ after induction. Black arrow points to protein band, PFN1, expressed the most at $0.4 \mathrm{mM}$ IPTG in the case of WT PFN1 and at 0.8 $\mathrm{mM}$ IPTG for PFN1 ${ }^{\mathrm{G} 117 \mathrm{~V}}$.

Figure 2S. Coomassie blue stained SDS-PAGE related to the time of induction optimization of $\mathrm{PFN} 1^{\mathrm{WT}}$ and PFN1 ${ }^{\mathrm{G} 117 \mathrm{~V}}$, from left to right: Ladder, before induction (BI), $2 \mathrm{~h}, 4 \mathrm{~h}$ and $20 \mathrm{~h}$ after induction (PFN1 ${ }^{\mathrm{WT}}$ ), before induction (BI), $2 \mathrm{~h}, 4 \mathrm{~h}$ and $20 \mathrm{~h}$ after induction $\left(\mathrm{PFN} 1^{\mathrm{G} 117 \mathrm{~V}}\right)$. Black arrow points to protein band, $\mathrm{PFN} 1^{\mathrm{G} 117 \mathrm{~V}}$, that required $20 \mathrm{hrs}$ of induction for either WT or mutant PFN1.

Figure 3S. Sonication of the bacterial cells at $20^{\circ} \mathrm{C}$ related to PFN1 ${ }^{\mathrm{WT}}$ and $\mathrm{PFN} 1^{\mathrm{G} 117 \mathrm{~V}}$. From left to right; a. Ladder, before induction (BI), before sonic (BS), after sonic (AS), pellet after centrifugation in $2000 \mathrm{rpm}$ (P2000), supernatant after centrifugation in $2000 \mathrm{rpm}$ (S2000), supernatant after centrifugation in $13000 \mathrm{rpm}$ (S13000) and pellet after centrifugation in 13000 rpm (P13000). b. Ladder, before induction (BI), before sonic (BS), after sonic (AS), pellet after centrifugation in $2000 \mathrm{rpm}$ (P2000), supernatant after centrifugation in $2000 \mathrm{rpm}$ (S2000), supernatant after centrifugation in $13000 \mathrm{rpm}$ (S13000) and pellet after centrifugation in 13000 rpm (P13000). Arrow points to most pure PFN1 at S13000 rpm. 
Tables:

Table 1.

\begin{tabular}{|c|c|c|c|}
\hline Structures & Molecular Formula & 2D Structure & 3D Structure \\
\hline Acetaldehyde & $\begin{array}{l}\mathrm{C} 2 \mathrm{H} 4 \mathrm{O} \text { or } \mathrm{CH} 3 \mathrm{CHO} \\
\mathrm{CID}: 177 \\
\text { CAS: } 75-05-0\end{array}$ & H & \\
\hline & & \multicolumn{2}{|c|}{ \#opt b3lyp/3-21g geom =connectivity } \\
\hline Benzaldehyde & $\begin{array}{l}\text { C7H6O or } \mathrm{C} 6 \mathrm{H} 5 \mathrm{CHO} \\
\text { CID : } 240 \\
\text { CAS : } 100-52-7\end{array}$ & & \\
\hline
\end{tabular}


Table 2:

\begin{tabular}{|l|c|c|c|c|c|c|c|}
\hline Sample & $\begin{array}{c}\text { MW } \\
\text { (Da) }\end{array}$ & $\begin{array}{c}\text { Amino } \\
\text { acids }\end{array}$ & $\mathbf{1 0}$ s & $\begin{array}{c}\mathbf{2} \\
\mathbf{m i n}\end{array}$ & $\begin{array}{c}\mathbf{4} \\
\mathbf{m i n}\end{array}$ & $\begin{array}{c}\mathbf{1 0} \\
\text { min }\end{array}$ & $\mathbf{7 ~ h}$ \\
\hline PFN1 $^{\mathrm{WT}}$ & 16,763 & 140 & 23 & 40 & 86 & 97 & 238 \\
\hline PFN1 $^{\mathrm{G} 117 \mathrm{~V}}$ & 16,662 & 140 & 14 & 40 & 65 & 133 & 242 \\
\hline
\end{tabular}




\begin{tabular}{|c|c|c|c|c|c|c|c|c|}
\hline Sample & $\begin{array}{l}\mathrm{MW}, \\
\text { (Da) }\end{array}$ & $\begin{array}{l}\text { Amino } \\
\text { acids }\end{array}$ & $\begin{array}{l}\quad \text { Ami } \\
\text { no acids } \\
\text { in found } \\
\text { in the } \\
\text { crystal } \\
\text { structur } \\
\text { e data }\end{array}$ & $\begin{array}{l}\quad \text { Amin } \\
\text { o acids } \\
\text { that } \\
\text { participa } \\
\text { ted in } \\
\text { PFN1- } \\
\text { acetalde } \\
\text { hyde } \\
\text { interacti } \\
\text { on } \\
\text { accordin } \\
\text { g to the } \\
\text { lowest } \\
\text { binding } \\
\text { energy }\end{array}$ & $\begin{array}{l}\quad \text { Accessi } \\
\text { ble } \\
\text { hydrogen } \\
\text { in } \\
\text { molecular } \\
\text { docking } \\
\text { simulation } \\
\text { in PFN1- } \\
\text { acetaldehy } \\
\text { de } \\
\text { complex }\end{array}$ & $\begin{array}{l}\quad \text { Amin } \\
\text { o acids } \\
\text { that } \\
\text { participa } \\
\text { ted in } \\
\text { PFN1- } \\
\text { benzalde } \\
\text { hyde } \\
\text { interacti } \\
\text { on }\end{array}$ & $\begin{array}{l}\text { Accessi } \\
\text { ble } \\
\text { hydrogen } \\
\text { in } \\
\text { molecular } \\
\text { docking } \\
\text { simulation } \\
\text { in PFN1- } \\
\text { benzaldeh } \\
\text { yde } \\
\text { complex }\end{array}$ & $\begin{array}{l}\text { Total } \\
\text { number } \\
\text { of } \\
\text { accessib } \\
\text { le } \\
\text { hydroge } \\
\text { ns }\end{array}$ \\
\hline${ }_{\mathrm{T}} \mathrm{PFN}^{\mathrm{W}}$ & 16763 & 140 & 139 & $\begin{array}{l}\text { Q79, } \\
\text { T64, } \\
\text { K25, } \\
\text { N99, } \\
\text { L78 }\end{array}$ & 22 & $\begin{array}{l}\text { T31, } \\
\text { R74, } \\
\text { R135 }\end{array}$ & 18 & 40 \\
\hline${ }_{17 \mathrm{~V}} \mathrm{PFN}^{\mathrm{G} 1}$ & 16662 & 140 & 139 & $\begin{array}{l}\quad \mathrm{R} 55, \\
\text { Y24, } \\
\text { K25, } \\
\text { T59,V60 } \\
\text {, F83 }\end{array}$ & 16 & $\begin{array}{l}\quad \mathrm{V} 118, \\
\text { K104, } \\
\text { D54,N12 } \\
4, \\
\text { I123,Y5 } \\
9, \\
\text { D106,D2 } \\
5, \text { Y54 }\end{array}$ & 37 & 53 \\
\hline
\end{tabular}

Table 3 
Supplementary Tables:

Table 1S.

\begin{tabular}{|c|c|c|c|c|}
\hline $\begin{array}{c}\text { Cluster } \\
\text { Rank }\end{array}$ & $\begin{array}{c}\text { Lowest Binding } \\
\text { Energy(kcal/mol) }\end{array}$ & Run & $\begin{array}{c}\text { Mean Binding } \\
\text { Energy } \\
\text { (kcal/mol) }\end{array}$ & $\begin{array}{c}\text { Numbers of } \\
\text { Clusters }\end{array}$ \\
\hline 1 & -2.89 & 113 & -2.80 & 197 \\
\hline 2 & -2.49 & 13 & -2.43 & 4 \\
\hline 3 & -2.47 & 180 & -2.47 & 16 \\
\hline 4 & -2.28 & 39 & -2.28 & 3 \\
\hline
\end{tabular}


Table 2S.

\begin{tabular}{|c|c|c|c|c|}
\hline $\begin{array}{c}\text { Cluster } \\
\text { Rank }\end{array}$ & $\begin{array}{c}\text { Lowest Binding } \\
\text { Energy(kcal/mol) }\end{array}$ & Run & $\begin{array}{c}\text { Mean Binding } \\
\text { Energy } \\
\text { (kcal/mol) }\end{array}$ & $\begin{array}{c}\text { Number in } \\
\text { Cluster }\end{array}$ \\
\hline 1 & -2.68 & 159 & -2.67 & 183 \\
\hline 2 & -2.55 & 78 & -2.54 & 18 \\
\hline 3 & -2.32 & 44 & -2.32 & 1 \\
\hline 4 & -2.32 & 151 & -2.32 & 18 \\
\hline
\end{tabular}


Table 3S.

\begin{tabular}{|c|c|c|c|c|}
\hline $\begin{array}{c}\text { Cluster } \\
\text { Rank }\end{array}$ & $\begin{array}{c}\text { Lowest Binding } \\
\text { Energy(kcal/mol) }\end{array}$ & Run & $\begin{array}{c}\text { Mean Binding } \\
\text { Energy(kcal/mol) }\end{array}$ & $\begin{array}{c}\text { Number in } \\
\text { Cluster }\end{array}$ \\
\hline 1 & -3.80 & 128 & -3.77 & 21 \\
\hline 2 & -3.77 & 27 & -3.76 & 163 \\
\hline 3 & -3.75 & 80 & -3.74 & 14 \\
\hline 4 & -3.74 & 14 & -3.70 & 15 \\
\hline 5 & -3.67 & 107 & -3.67 & 2 \\
\hline 6 & -3.56 & 143 & -3.56 & 2 \\
\hline 7 & -3.54 & 94 & -3.52 & 2 \\
\hline 8 & -3.51 & 73 & -3.50 & 1 \\
\hline
\end{tabular}


Table 4S.

\begin{tabular}{|c|c|c|c|c|}
\hline $\begin{array}{c}\text { Cluster } \\
\text { Rank }\end{array}$ & $\begin{array}{c}\text { Lowest Binding } \\
\text { Energy(kcal/mol) }\end{array}$ & Run & $\begin{array}{c}\text { Mean Binding } \\
\text { Energy(kcal/mol) }\end{array}$ & $\begin{array}{c}\text { Number in } \\
\text { Cluster }\end{array}$ \\
\hline 1 & -4.42 & 240 & -4.39 & 130 \\
\hline 2 & -4.40 & 40 & -4.39 & 14 \\
\hline 3 & -3.92 & 10 & -3.88 & 50 \\
\hline 4 & -3.84 & 69 & -3.83 & 9 \\
\hline 5 & -3.76 & 110 & -3.72 & 15 \\
\hline 6 & -3.60 & 118 & -3.60 & 2 \\
\hline
\end{tabular}


Figures:

Fig. 1.

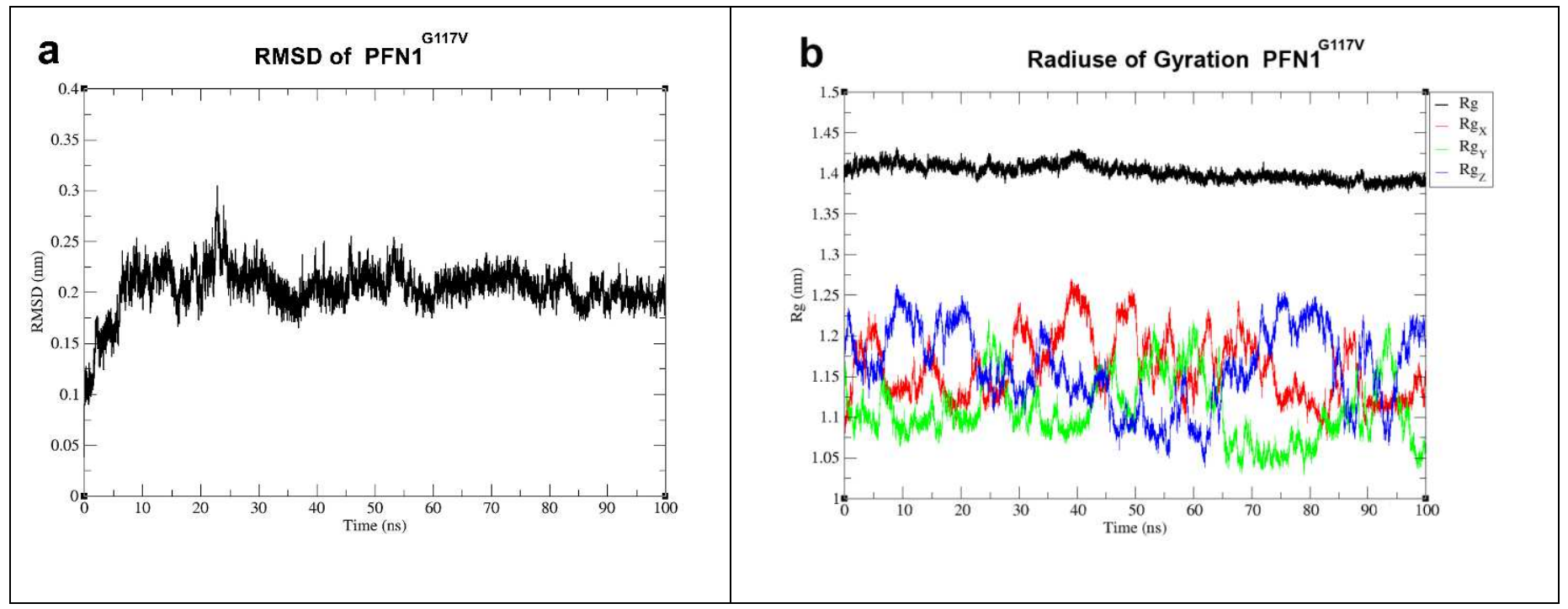


Fig. 2.

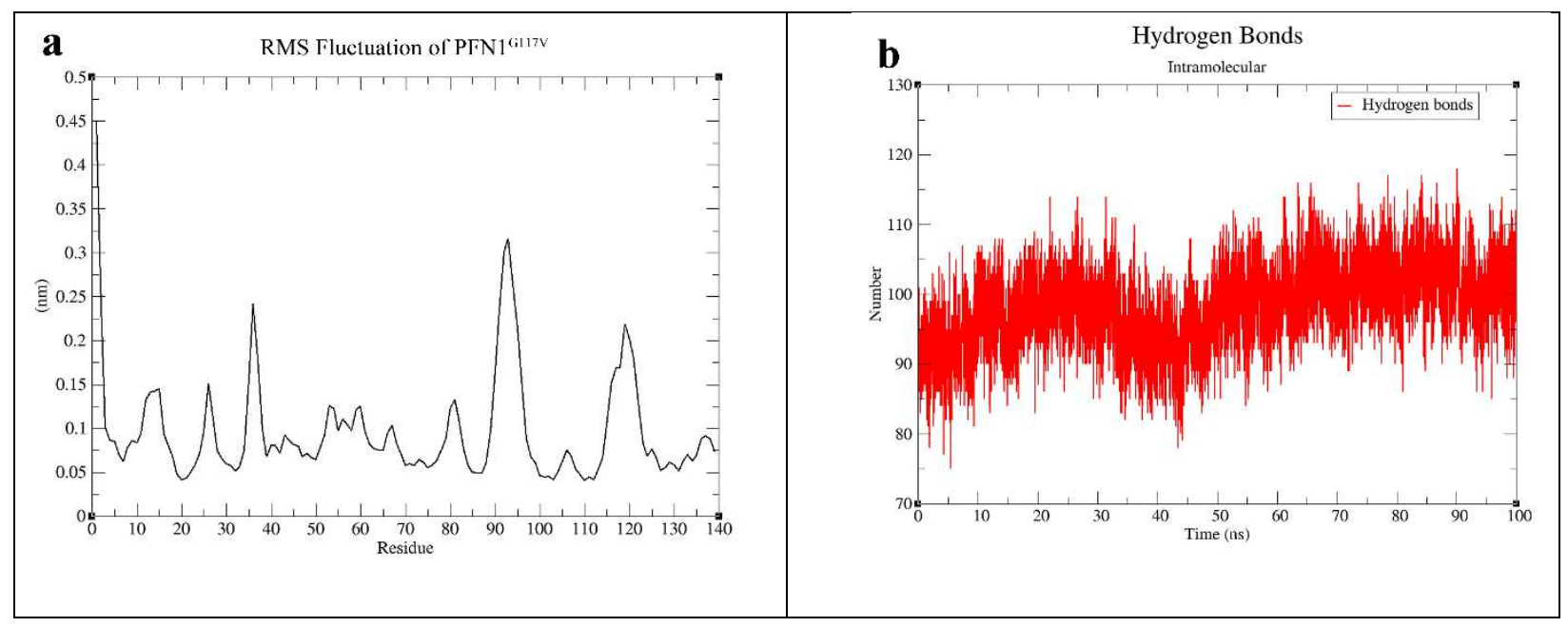


Fig. 3.

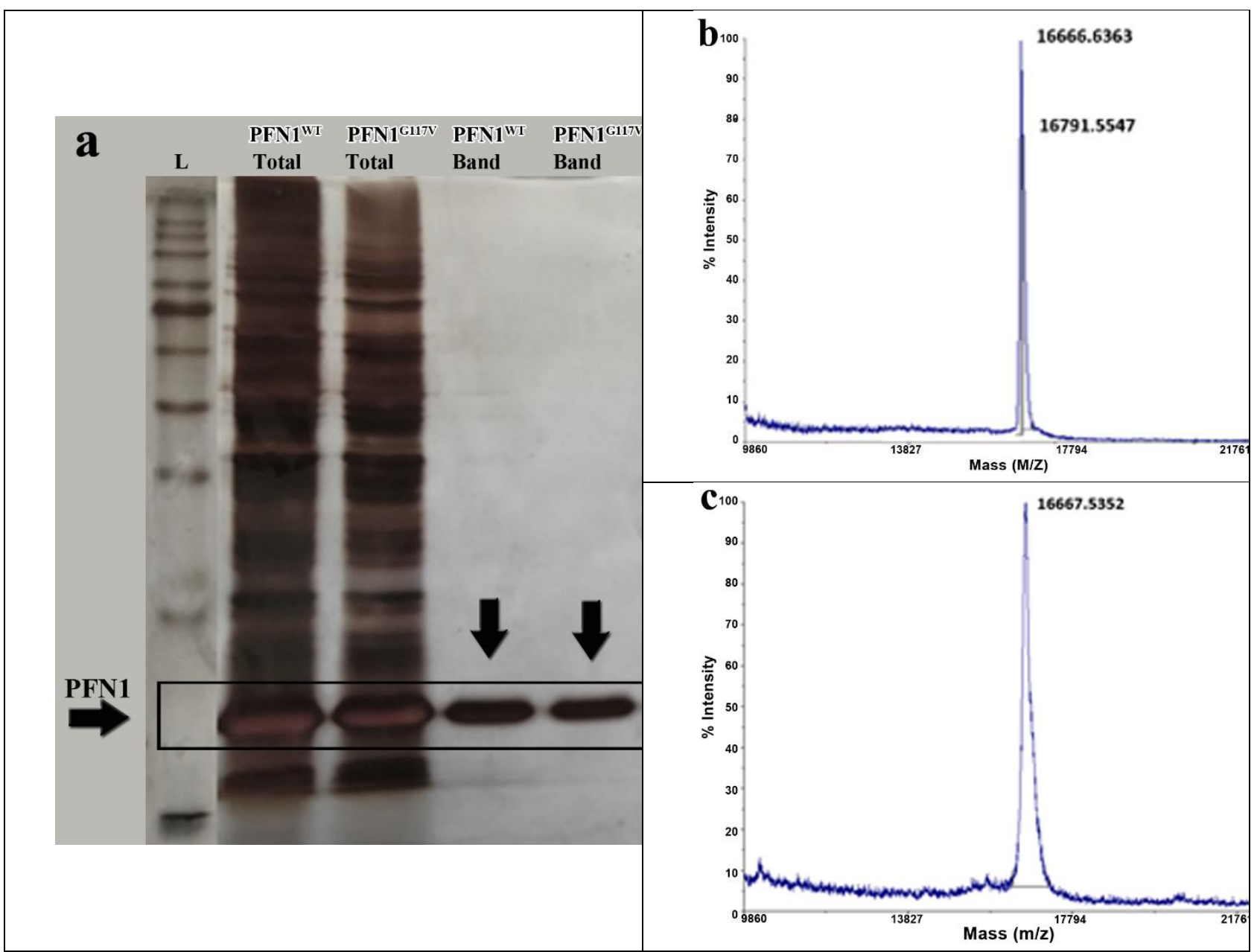


Fig. 4.

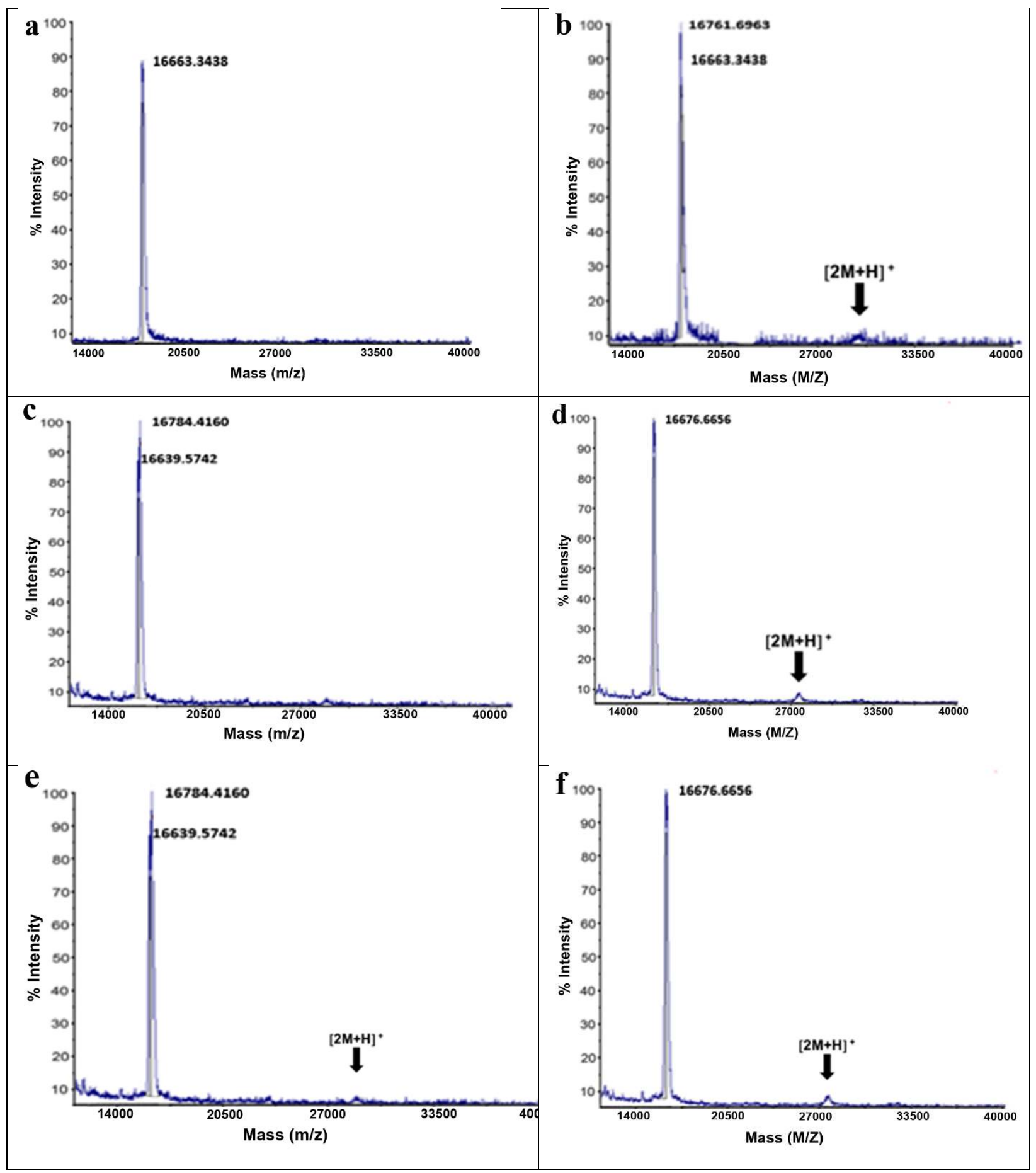




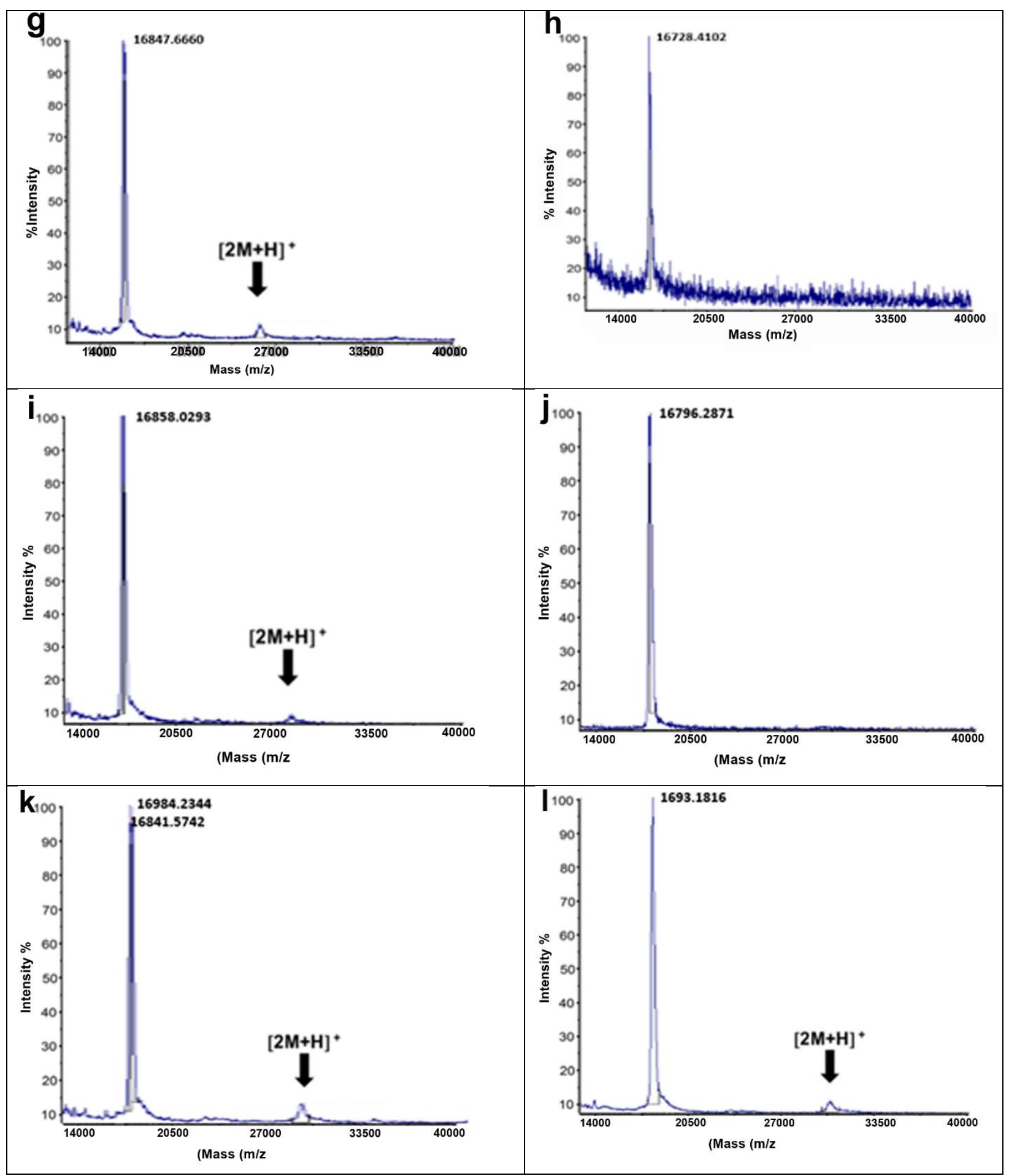


Fig. 5.

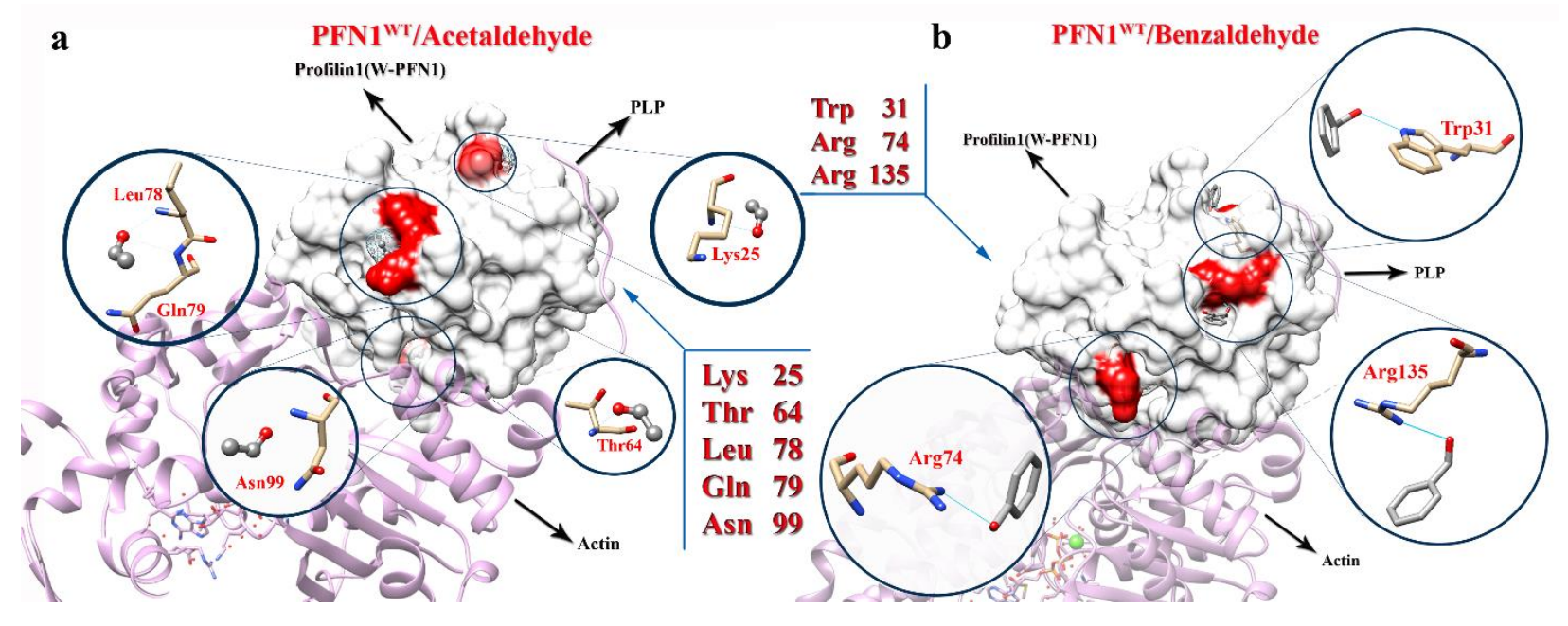


Fig. 6.

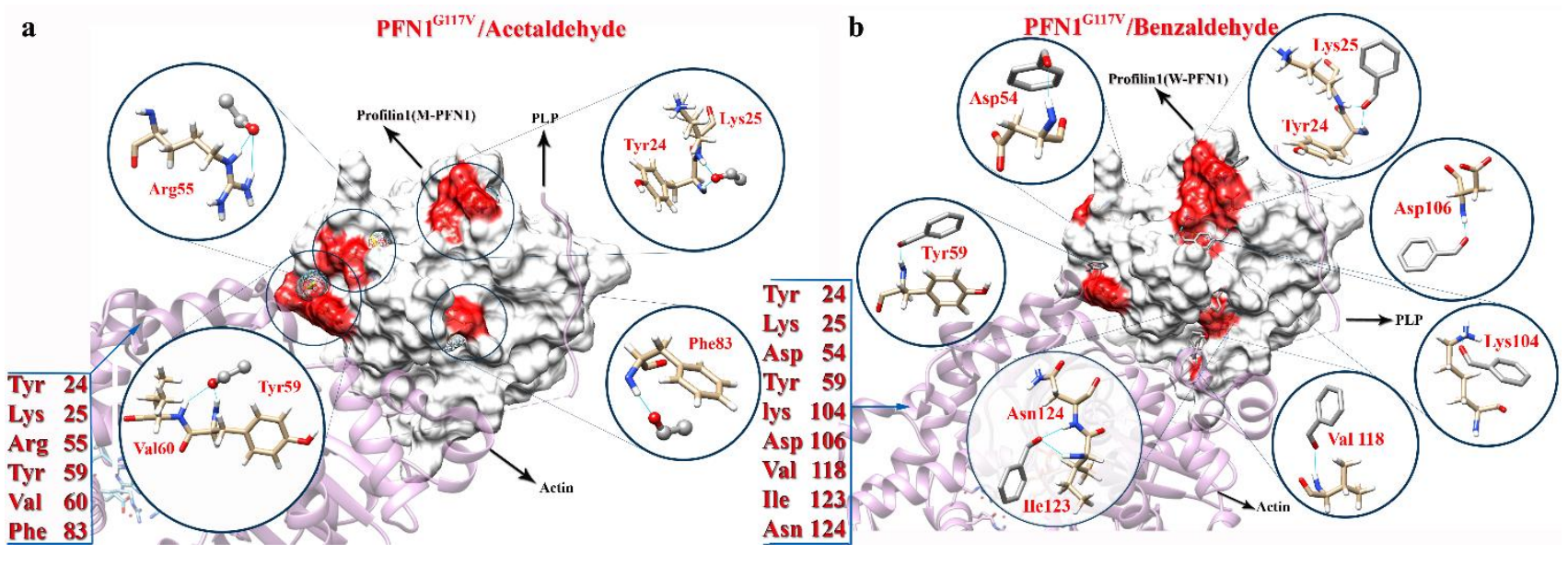


Supplementary data:

Fig.1S.

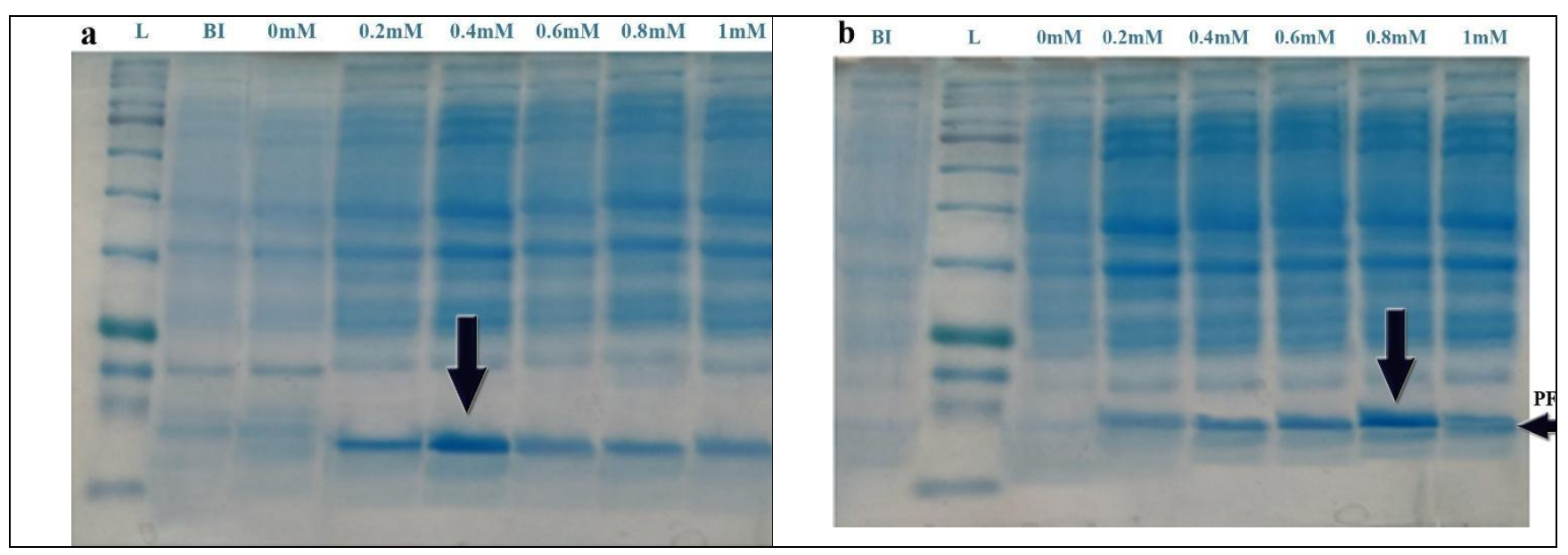


Fig. 2S.

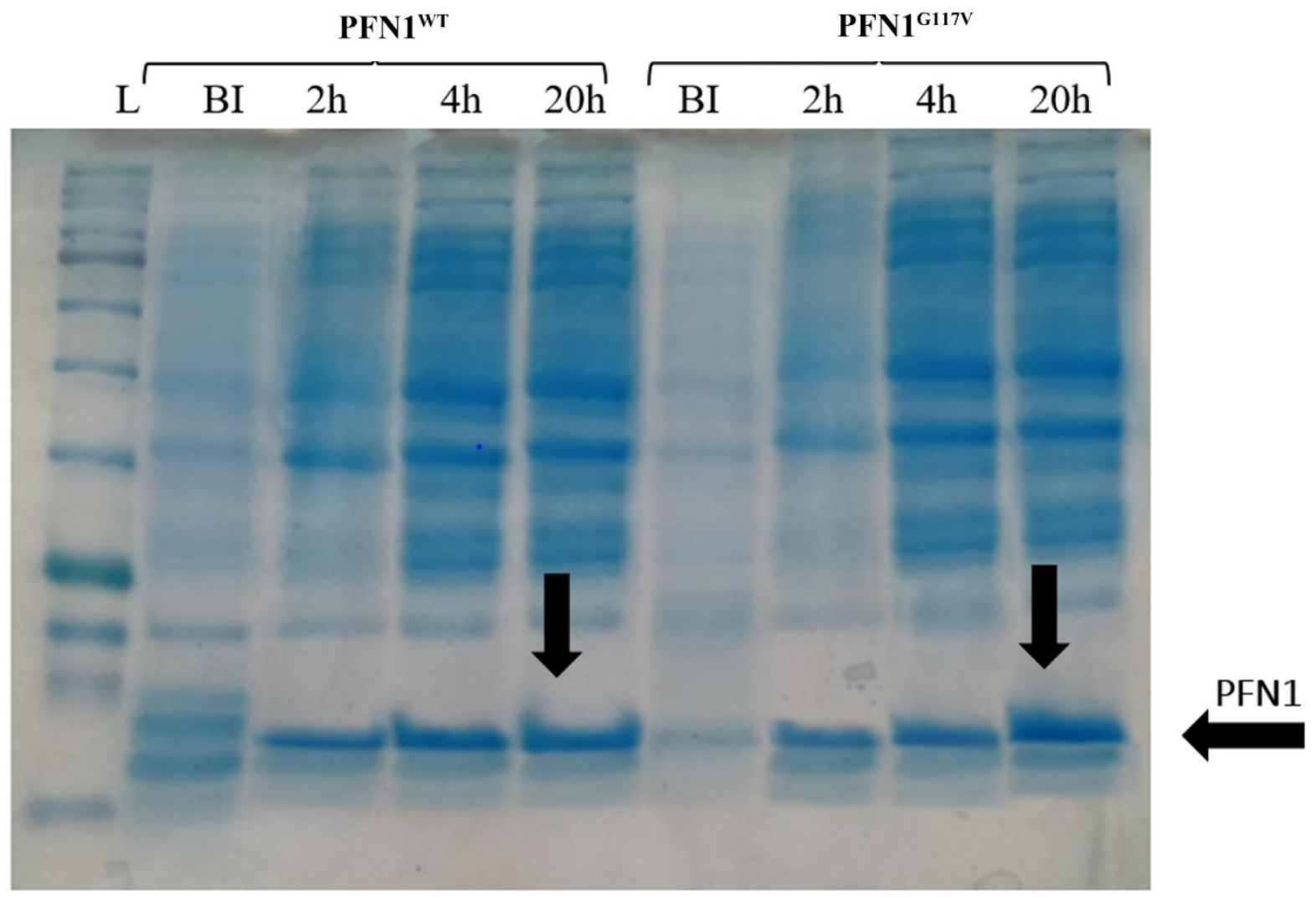


Fig. 3S.

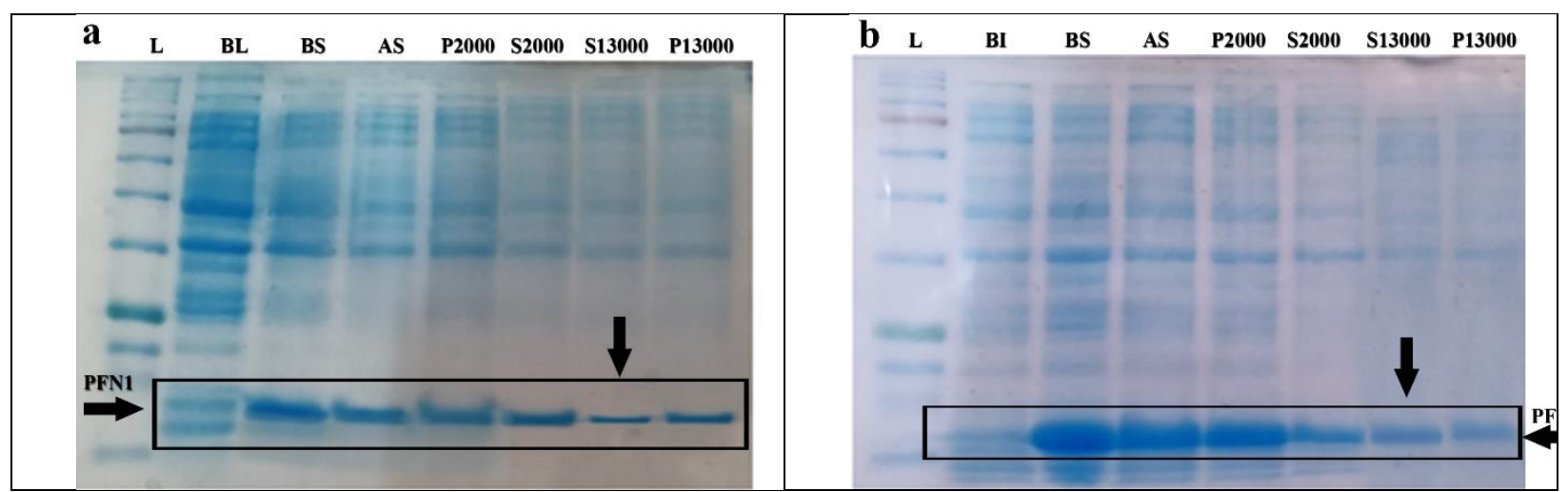




\section{Supplementary Movie.}

Supp. Movie. An animation of molecular simulation of mutant PFN1 ${ }^{\mathrm{G} 117 \mathrm{~V}}$ and Wild type with small molecules (Acetaldehyde and Benzaldehyde) to demonstrate the hotspots and amino acids involved on the surface of PFN1 in relation to Actin, PLP. https://doi.org/10.6084/m9.figshare.13551218 


\section{Compliance with Ethical Standards}

\section{Disclosure of potential conflicts of interest:}

Dr. Kiaei is the founder, President and CEO of RockGen Therapeutics, LLC., and have a financial interest in the technology discussed in this publication. These financial interests have been reviewed and approved in accordance with the RockGen conflict of interest policies. Other authors have no conflict.

\section{Research involving human participants and/or animals}

There were no human participants or animals used in this study.

\section{Informed consent:}

\section{N/A}

\section{Ethical approval:}

This article does not contain any studies with human participants or animals performed by any of the authors.

\section{Funding Supports:}

We acknowledge the support from RockGen Therapeutics, LLC. There is no other financial support to disclose. 


\section{References}

Alkam, D., E. Z. Feldman, A. Singh and M. Kiaei (2017). "Profilin1 biology and its mutation, actin (g) in disease." Cellular and Molecular Life Sciences 74(6): 967-981.

Busenlehner, L. S. and R. N. Armstrong (2005). "Insights into enzyme structure and dynamics elucidated by amide H/D exchange mass spectrometry." Archives of biochemistry and biophysics 433(1): 34-46.

Chen, Y., R. Huang, K. Chen, W. Song, B. Zhao, X. Chen, Y. Yang, L. Yuan and H.-F. Shang (2013). "PFN1 mutations are rare in Han Chinese populations with amyotrophic lateral sclerosis." Neurobiology of aging 34(7): 1922. e1921-1922. e1925.

Englander, J. J., C. Del Mar, W. Li, S. W. Englander, J. S. Kim, D. D. Stranz, Y. Hamuro and V. L. Woods (2003). "Protein structure change studied by hydrogen-deuterium exchange, functional labeling, and mass spectrometry." Proceedings of the National Academy of Sciences 100(12): 7057-7062.

Englander, S. W. (2006). "Hydrogen exchange and mass spectrometry: A historical perspective." Journal of the American Society for Mass Spectrometry 17(11): 1481-1489.

Fedorov, A., T. Pollard and S. C. Almo (1994). "Purification, characterization and crystallization of human platelet profilin expressed in Escherichia coli." Journal of molecular biology 241(3): 480-482.

Ferrin, T. E., C. C. Huang, L. E. Jarvis and R. Langridge (1988). "The MIDAS display system." Journal of molecular graphics 6(1): 13-27.

Figueroa, I. D. and D. H. Russell (1999). "Matrix-assisted laser desorption ionization hydrogen/deuterium exchange studies to probe peptide conformational changes." Journal of the American Society for Mass Spectrometry 10(8): 719-731.

Fil, D., A. DeLoach, S. Yadav, D. Alkam, M. MacNicol, A. Singh, C. M. Compadre, J. J. Goellner, C. A. O’Brien and T. Fahmi (2017). "Mutant Profilin1 transgenic mice recapitulate cardinal features of motor neuron disease." Human molecular genetics 26(4): ddw429.

Frisch, M., G. Trucks, H. Schlegel, G. Scuseria, M. Robb, J. Cheeseman, J. Montgomery and T. Vreven (2004). udin, KN.; Burant, JC., et al. Gaussian 03, Version C. 02. Wallingford, CT: Gaussian, Inc.

Gaussian03, R. B. (2004). "05, MJ Frisch et al., Gaussian." Inc., Wallingford CT.

Hentze, N. and M. P. Mayer (2013). "Analyzing protein dynamics using hydrogen exchange mass spectrometry." JoVE (Journal of Visualized Experiments)(81): e50839.

Hospital, A., J. R. Goñi, M. Orozco and J. L. Gelpí (2015). "Molecular dynamics simulations: advances and applications." Advances and applications in bioinformatics and chemistry: AABC 8: 37 .

Kiaei, M., M. Balasubramaniam, V. G. Kumar, R. J. S. Reis, M. Moradi and K. I. Varughese (2018). "ALS-causing mutations in profilin-1 alter its conformational dynamics: a computational approach to explain propensity for aggregation." Scientific reports 8(1): 1-10. 
Kim, S., J. Chen, T. Cheng, A. Gindulyte, J. He, S. He, Q. Li, B. A. Shoemaker, P. A. Thiessen and B. Yu (2019). "PubChem 2019 update: improved access to chemical data." Nucleic acids research 47(D1): D1102-D1109.

Kochert, B. A., R. E. Iacob, T. E. Wales, A. Makriyannis and J. R. Engen (2018). Hydrogendeuterium exchange mass spectrometry to study protein complexes. Protein Complex Assembly, Springer: $153-171$.

Krishnan, K., O. Holub, E. Gratton, A. H. Clayton, S. Cody and P. D. Moens (2009). "Profilin interaction with phosphatidylinositol $(4,5)$-bisphosphate destabilizes the membrane of giant unilamellar vesicles." Biophysical journal 96(12): 5112-5121.

Lambrechts, A., V. Jonckheere, D. Dewitte, J. Vandekerckhove and C. Ampe (2002). "Mutational analysis of human profilin I reveals a second PI (4, 5)-P 2 binding site neighbouring the poly (L-proline) binding site." BMC biochemistry 3(1): 12.

Lee, S. and H.-J. Kim (2015). "Prion-like mechanism in amyotrophic lateral sclerosis: are protein aggregates the key?" Experimental neurobiology 24(1): 1-7.

Lemkul, J. (2018). "From proteins to perturbed Hamiltonians: A suite of tutorials for the GROMACS-2018 molecular simulation package [article v1. 0]." Living Journal of Computational Molecular Science 1(1): 5068.

Leurs, U., U. H. Mistarz and K. D. Rand (2015). "Getting to the core of protein pharmaceuticals-Comprehensive structure analysis by mass spectrometry." European Journal of Pharmaceutics and Biopharmaceutics 93: 95-109.

Lodowski, D. T., K. Palczewski and M. Miyagi (2010). "Conformational Changes in the G Protein-Coupled Receptor Rhodopsin Revealed by Histidine Hydrogen- Deuterium Exchange." Biochemistry 49(44): 9425-9427.

Maier, C. S. and M. L. Deinzer (2005). "Protein conformations, interactions, and H/D exchange." Methods in enzymology 402: 312-360.

Majumdar, R., C. R. Middaugh, D. D. Weis and D. B. Volkin (2015). "Hydrogen-deuterium exchange mass spectrometry as an emerging analytical tool for stabilization and formulation development of therapeutic monoclonal antibodies." Journal of pharmaceutical sciences 104(2): 327-345.

Metzler, W. J., B. T. Farmer, K. L. Constantine, M. S. Friedrichs, L. Mueller and T. Lavoie (1995). "Refined solution structure of human profilin I." Protein Science 4(3): 450-459.

Montalvao, R. W., A. Cavalli, X. Salvatella, T. L. Blundell and M. Vendruscolo (2008). "Structure determination of protein- protein complexes using NMR chemical shifts: case of an endonuclease colicin- immunity protein complex." Journal of the American Chemical Society 130(47): 15990-15996.

Morris, G. M., R. Huey, W. Lindstrom, M. F. Sanner, R. K. Belew, D. S. Goodsell and A. J. Olson (2009). "AutoDock4 and AutoDockTools4: Automated docking with selective receptor flexibility." J Comput Chem 30(16): 2785-2791. 
Nekouei, M., P. Ghezellou, A. Aliahmadi, S. Arjmand, M. Kiaei and A. Ghassempour (2018). "Changes in biophysical characteristics of PFN1 due to mutation causing amyotrophic lateral sclerosis." Metabolic brain disease 33(6): 1975-1984.

Ngan, C. H., T. Bohnuud, S. E. Mottarella, D. Beglov, E. A. Villar, D. R. Hall, D. Kozakov and S. Vajda (2012). "FTMAP: extended protein mapping with user-selected probe molecules." Nucleic acids research 40(W1): W271-W275.

Palashoff, M. H. (2008). Determining the specificity of pepsin for proteolytic digestion, Northeastern University.

Pettersen, E. F., T. D. Goddard, C. C. Huang, G. S. Couch, D. M. Greenblatt, E. C. Meng and T. E. Ferrin (2004). "UCSF Chimera-a visualization system for exploratory research and analysis." Journal of computational chemistry 25(13): 1605-1612.

Rozbesky, D., P. Man, D. Kavan, J. Chmelik, J. Cerny, K. Bezouska and P. Novak (2012). "Chemical cross-linking and H/D exchange for fast refinement of protein crystal structure." Analytical chemistry 84(2): 867-870.

Schutt, C. E., J. C. Myslik, M. D. Rozycki, N. C. Goonesekere and U. Lindberg (1993). "The structure of crystalline profilin- $\beta$-actin." Nature 365(6449): 810-816.

Shevchenko, A., H. Tomas, J. Havli, J. V. Olsen and M. Mann (2006). "In-gel digestion for mass spectrometric characterization of proteins and proteomes." Nature protocols 1(6): 2856-2860.

Villanueva, J., F. Canals, V. Villegas, E. Querol and F. X. Avilés (2000). "Hydrogen exchange monitored by MALDI-TOF mass spectrometry for rapid characterization of the stability and conformation of proteins." FEBS letters 472(1): 27-33.

Wales, T. E. and J. R. Engen (2006). "Hydrogen exchange mass spectrometry for the analysis of protein dynamics." Mass spectrometry reviews 25(1): 158-170.

Wei, H., J. Mo, L. Tao, R. J. Russell, A. A. Tymiak, G. Chen, R. E. Iacob and J. R. Engen (2014). "Hydrogen/deuterium exchange mass spectrometry for probing higher order structure of protein therapeutics: methodology and applications." Drug discovery today 19(1): 95-102.

Weis, D. D. (2016). Hydrogen exchange mass spectrometry of proteins: fundamentals, methods, and applications, John Wiley \& Sons.

West, G. M., E. Y. Chien, V. Katritch, J. Gatchalian, M. J. Chalmers, R. C. Stevens and P. R. Griffin (2011). "Ligand-dependent perturbation of the conformational ensemble for the GPCR $\beta 2$ adrenergic receptor revealed by HDX." Structure 19(10): 1424-1432.

Witke, W. (2004). "The role of profilin complexes in cell motility and other cellular processes." Trends in cell biology 14(8): 461-469.

Wu, C.-H., C. Fallini, N. Ticozzi, P. J. Keagle, P. C. Sapp, K. Piotrowska, P. Lowe, M. Koppers, D. McKenna-Yasek and D. M. Baron (2012). "Mutations in the profilin 1 gene cause familial amyotrophic lateral sclerosis." Nature 488(7412): 499-503.

Xiao, K., J. Chung and A. Wall (2015). "The power of mass spectrometry in structural characterization of GPCR signaling." Journal of Receptors and Signal Transduction 35(3): 213219. 
Xiao, K., Y. Zhao, M. Choi, H. Liu, A. Blanc, J. Qian, T. J. Cahill, X. Li, Y. Xiao and L. J. Clark (2018). "Revealing the architecture of protein complexes by an orthogonal approach combining HDXMS, CXMS, and disulfide trapping." nature protocols 13(6): 1403-1428.

Zarei, S., K. Carr, L. Reiley, K. Diaz, O. Guerra, P. F. Altamirano, W. Pagani, D. Lodin, G. Orozco and A. Chinea (2015). "A comprehensive review of amyotrophic lateral sclerosis." Surgical neurology international 6.

Zhang, L., D. R. Bell, B. Luan and R. Zhou (2019). "Exploring the binding mechanism between human profilin (PFN1) and polyproline-10 through binding mode screening." The Journal of Chemical Physics 150(1): 015102.

Zhang, Z. and D. L. Smith (1993). "Determination of amide hydrogen exchange by mass spectrometry: a new tool for protein structure elucidation." Protein Science 2(4): 522-531.

Zhou, M. and C. V. Robinson (2014). "Flexible membrane proteins: functional dynamics captured by mass spectrometry." Current opinion in structural biology 28: 122-130. 


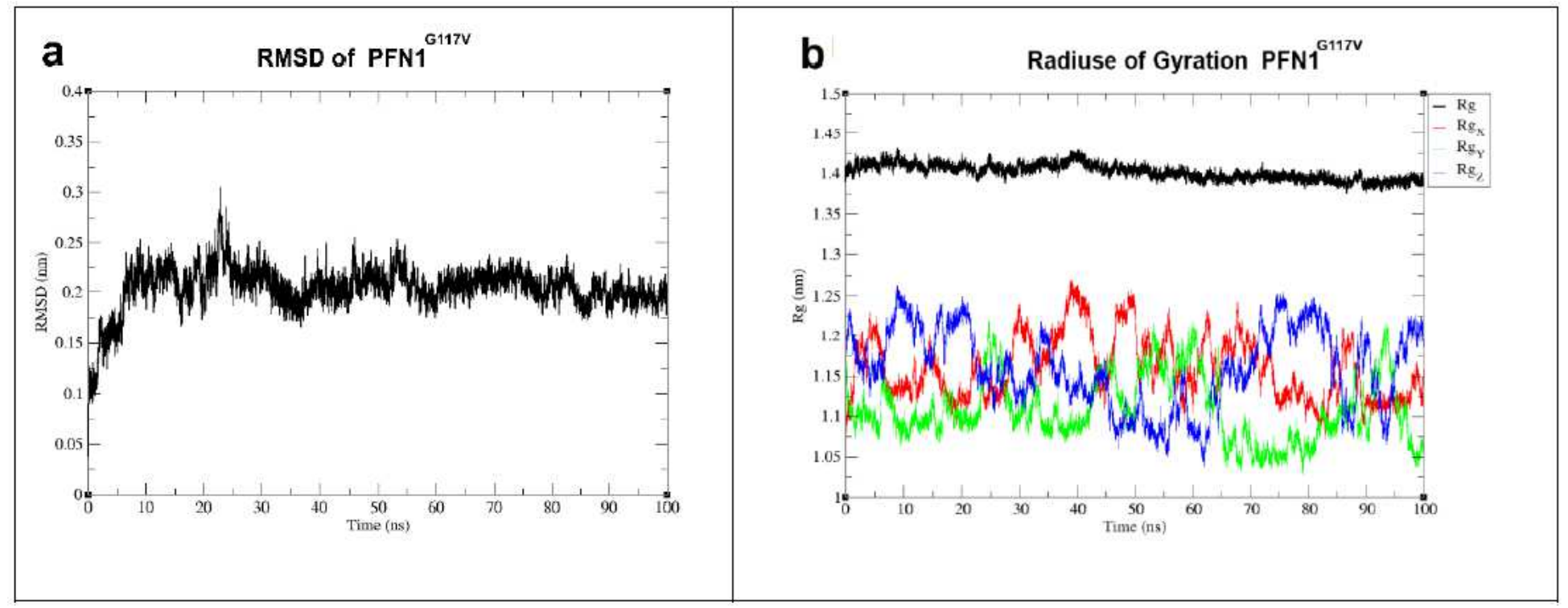

Figure 1

Backbone RMSD and Radius of Gyration (Rg) of PFN1G117V a. The RMSD for the backbone atoms of the mutant-type structure at 300k shown as a function of time. b. the Rg for the Ca atoms of the mutanttype PFN1 at 300k is shown as a function of time.

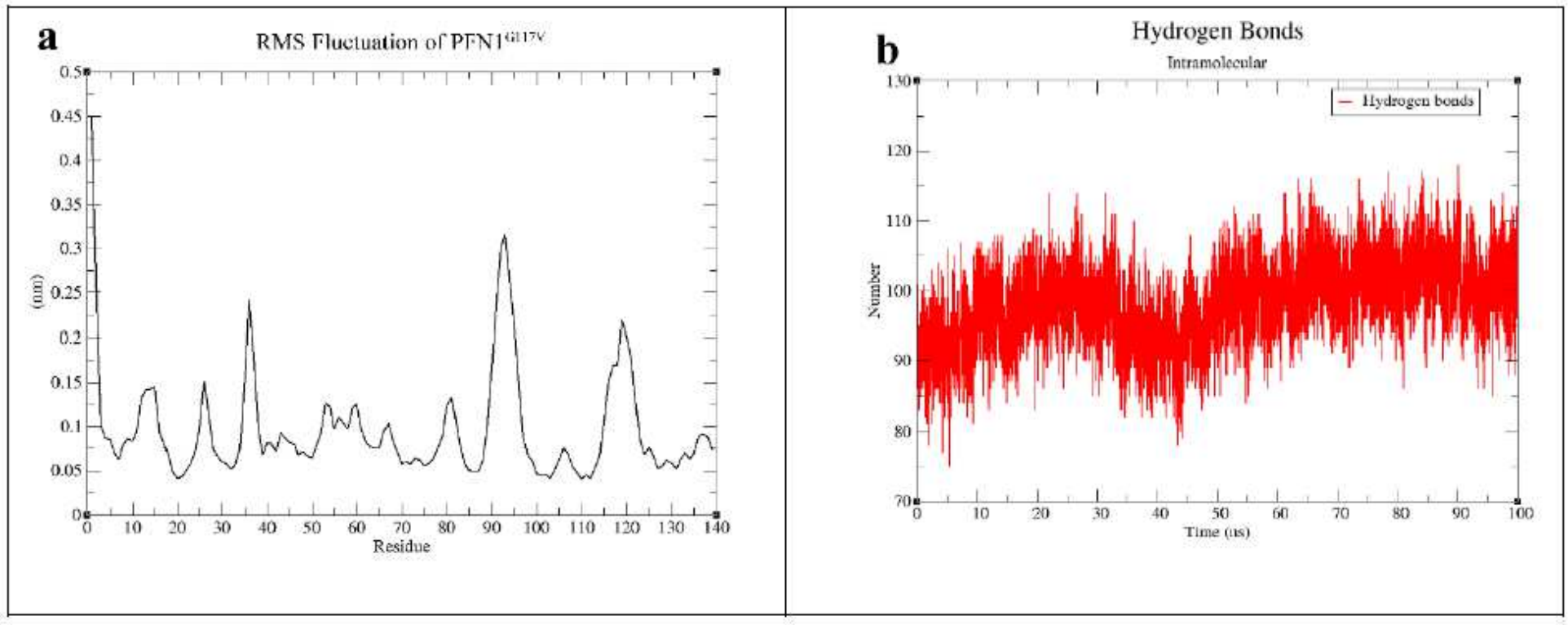

Figure 2

RMSF of the Mutant-type PFN1 and intramolecular hydrogen bond ( $\mathrm{Hb})$. a. The RMSF of the PFN1 Mutant type at 300k is shown. b. The number of intra-molecular $\mathrm{Hb}$ formed at $300 \mathrm{k}$ throughout the simulations is shown as a functions of time. 


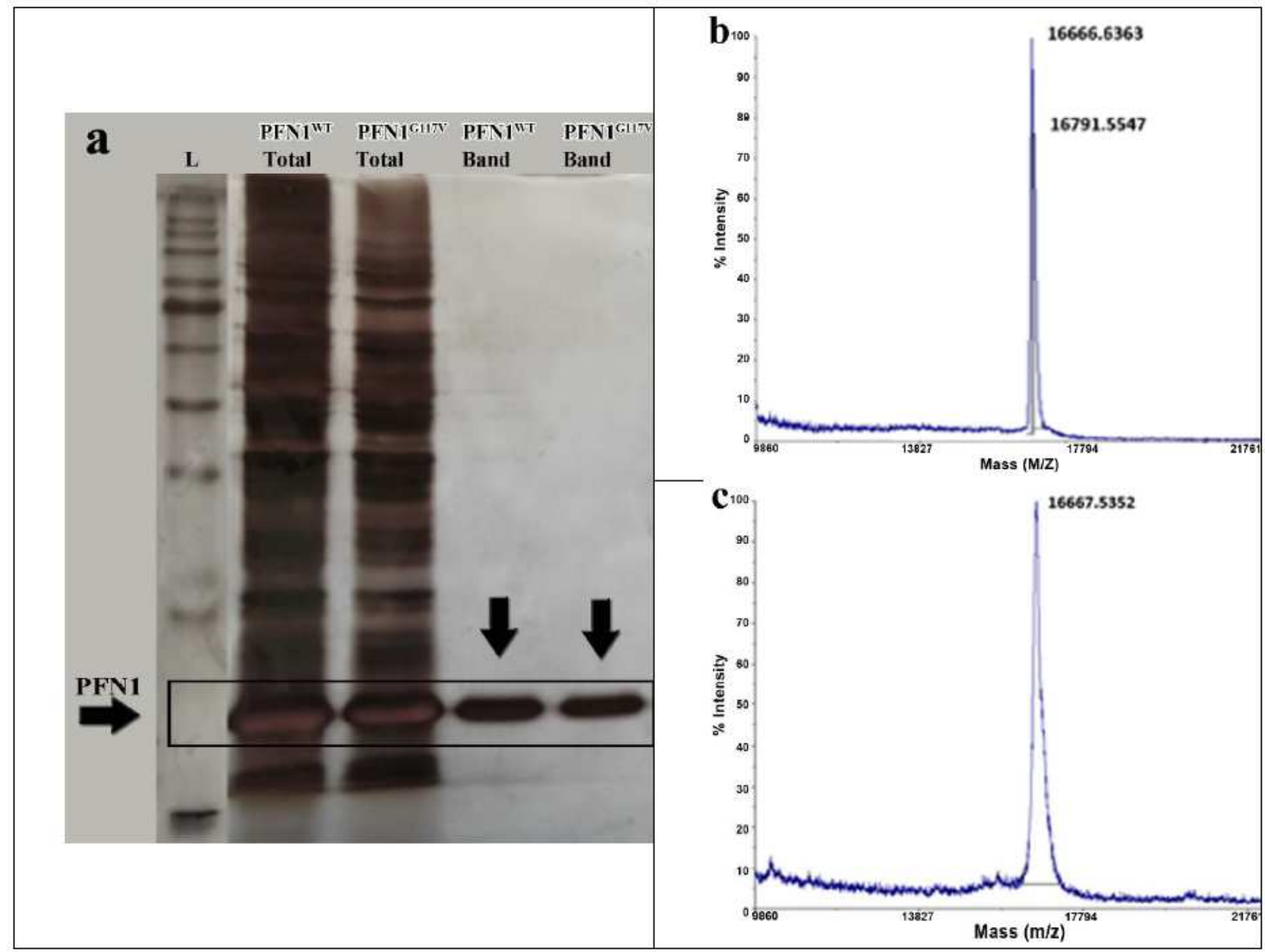

\section{Figure 3}

a. Silver nitrate staining in SDS-PAGE related to PFNWT and PFN1G117V purification using poly $\varangle \mathrm{L} \rrbracket$ proline sepharose column. Proteins band showed that in molecular weight of 14-15 kDa is related to PFN1 proteins. b. MALDI-TOF MS spectra related to intact PFN1WT. c. MALDI-TOF MS spectra related to intact PFN1G117V. Black arrows point to pure PFN1 band stained with silver staining. 


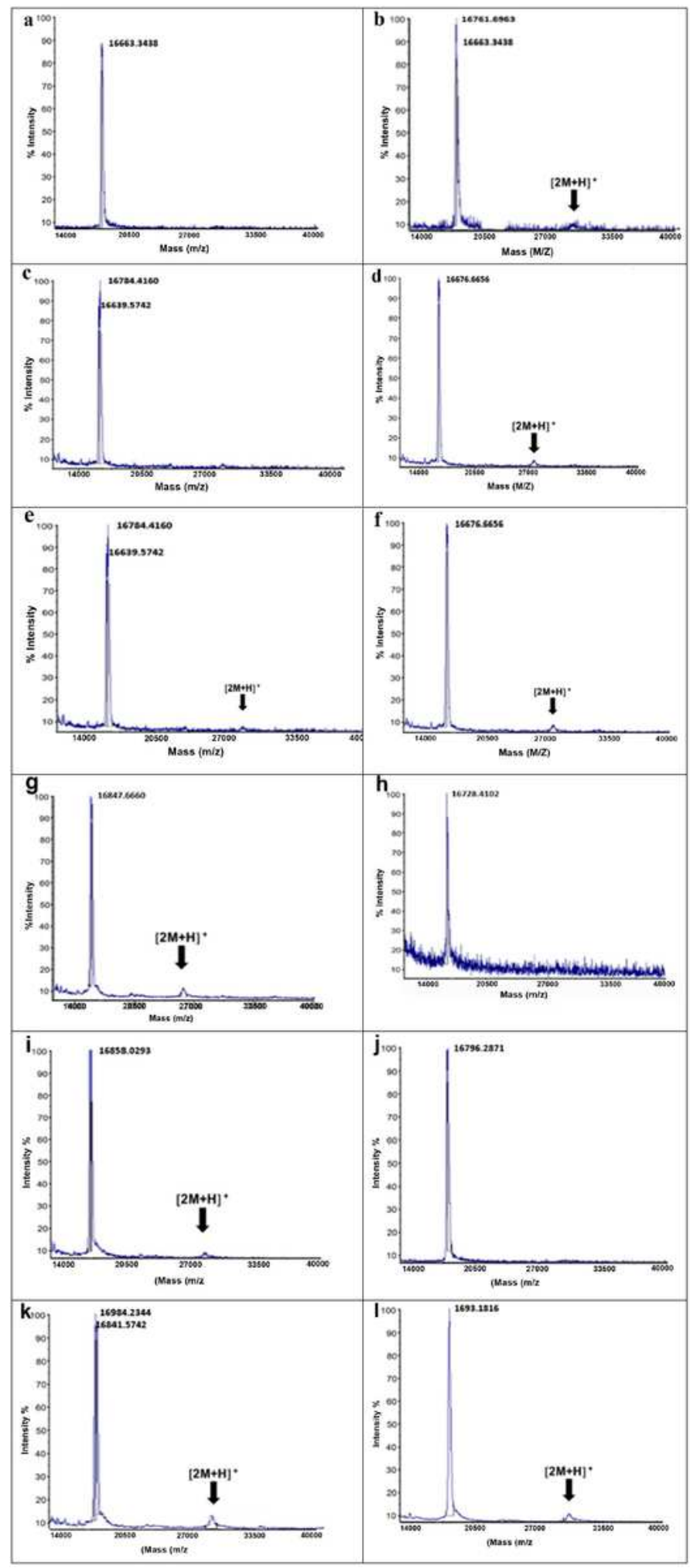

Figure 4

MALDI-TOF MS spectrum of time dependent deuterated and non-deuterated samples a. spectrum related to ND PFN1WT. b. The spectrum related to ND PFN1G117V. c. Pulse deuterated PFN1WT during 10s. $d$. Pulse deuterated PFN1G117V during 10s. e. Continues deuterated related to PFN1WT during 2 min. $f$. Continuous deuterated related to PFN1G117V during 2 min. g. Continuous deuterated related to PFN1WT during 4 min. h Continuous deuterated related to PFN1G117V during 4 min. i. Continuous deuterated 
related to PFN1WT during 10 min. j. Continuous deuterated related to PFN1G117V during $10 \mathrm{~min}$. k. Continuous deuterated related to PFN1WT during $7 \mathrm{~h}$. I. Continuous deuterated related to PFN1G117V during $7 \mathrm{~h}$.

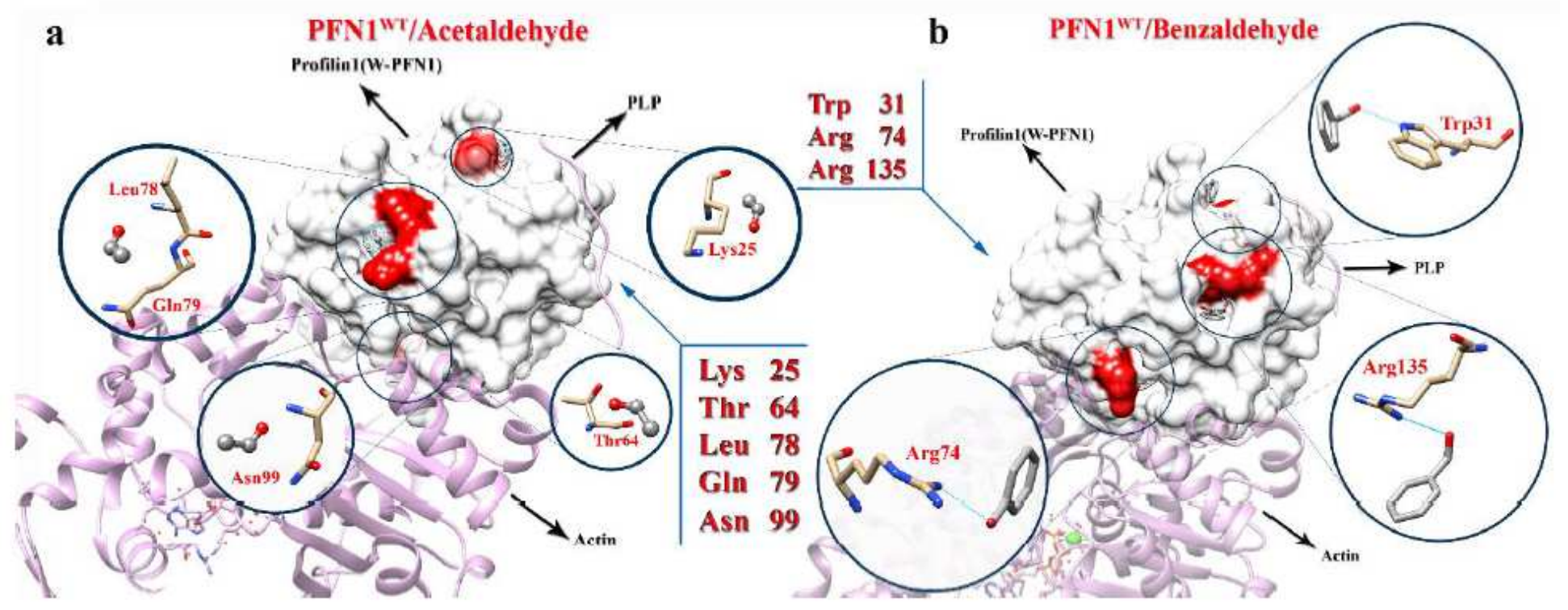

\section{Figure 5}

Molecular docking simulations of binding of PFN1WT to Acetaldehyde and Benzaldehyde. a. The hotspots amino acids on the surface of PFN1WT related to PFN1WT/Acetaldehyde by Lys25, Thr64, Leu78, GIn79 and Asn 99. b. The amino acids involved in the hotspots on the surface of PFN1WT related to PFN1WT/ Benzaldehyde are Trp31, Arg 74 and Arg135. An animated presentation of this data is available in supplementary data section. (Supp. movie)

a

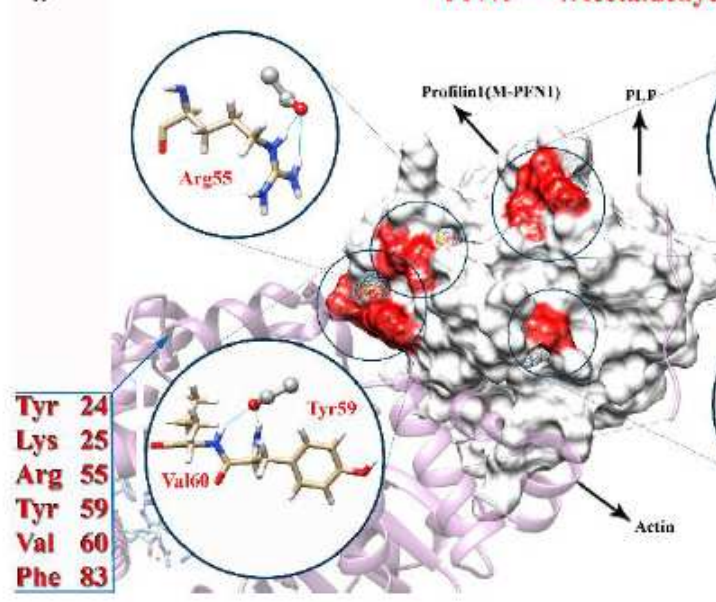

b
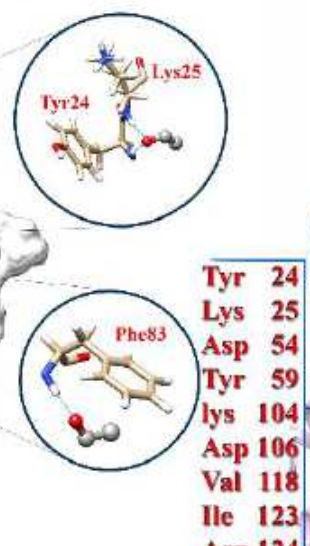

Asn 124

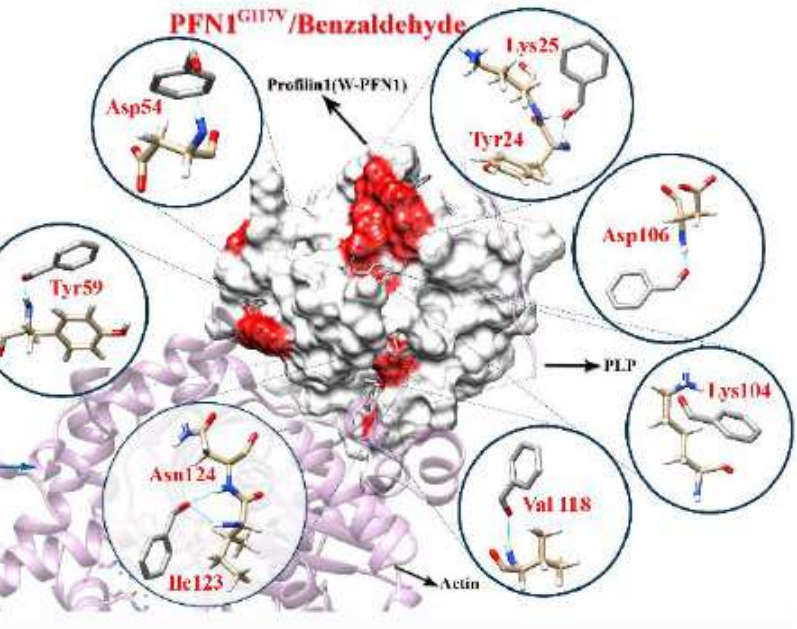

Figure 6

Molecular docking simulations of binding of PFN1G117V to Acetaldehyde and Benzaldehyde. a. The amino acids involved in the hotspots on the surface of PFN1G117V related to PFN1G117V/Acetaldehyde by Tyr24, Lys25, Arg55, Tyr59, Val60 and Phe83. b. The amino acids involved in the hotspots on the 
surface of PFN1G117V related to PFN1G117V/ Benzaldehyde are Tyr24, Lys25, Asp54, Tyr59, lys104, Asp106, Val118, Ile123, and Asn124. An animated presentation of this data is available in supplementary data section. (Supp. movie) 